\title{
Plant-Derived Smoke Affects Biochemical Mechanism on Plant Growth and Seed Germination
}

\author{
Amana Khatoon ${ }^{1}$, Shafiq Ur Rehman ${ }^{2}$, Muhammad Mudasar Aslam ${ }^{3}$, Muhammad Jamil ${ }^{4}$ (D) \\ and Setsuko Komatsu $5, *$ (D) \\ 1 Department of Botanical \& Environmental Sciences, Kohat University of Science \& Technology, \\ Kohat 26000, Pakistan; proteomics.sp@gmail.com \\ 2 Department of Biology, University of Haripur, Haripur 22620, Pakistan; drshafiq@yahoo.com \\ 3 Department of Botany, University of Science \& Technology Bannu, Bannu 28100, Pakistan; \\ mudasar_kust@yahoo.com \\ 4 Department of Biotechnology \& Genetic Engineering, Kohat University of Science \& Technology, \\ Kohat 26000, Pakistan; jamilkhattak@yahoo.com \\ 5 Department of Environmental and Food Sciences, Fukui University of Technology, Fukui 910-8505, Japan \\ * Correspondence: skomatsu@fukui-ut.ac.jp; Tel.: +81-766-29-2466
}

Received: 2 September 2020; Accepted: 13 October 2020; Published: 20 October 2020

\begin{abstract}
The role of plant-derived smoke, which is changed in mineral-nutrient status, in enhancing germination and post-germination was effectively established. The majority of plant species positively respond to plant-derived smoke in the enhancement of seed germination and plant growth. The stimulatory effect of plant-derived smoke on normally growing and stressed plants may help to reduce economic and human resources, which validates its candidature as a biostimulant. Plant-derived smoke potentially facilitates the early harvest and increases crop productivity. Karrikins and cyanohydrin are the active compound in plant-derived smoke. In this review, data from the latest research explaining the effect of plant-derived smoke on morphological, physiological, biochemical, and molecular responses of plants are presented. The pathway for reception and interaction of compounds of plant-derived smoke at the cellular and molecular level of plant is described and discussed.
\end{abstract}

Keywords: plant-derived smoke; biostimulant; omics; seed germination; plant growth

\section{Introduction}

Plant-derived smoke is a well-known agent for promoting plant growth and development [1] and positively affects plant species from various habitats [2,3]. The seed germination cues associated with fire or post-fire environments were identified as heat, temperature, chemicals, and smoke [4]. On the other hand, smoke produced during fire was recognized as the major germination cue in post-fire environments [1,2]. Despite its potential as a post-fire cue for seed germination, burning of vegetation has many disadvantages. The negative impacts of the fire and smoke include killing the beneficial soil insects and microorganisms, loss of various minerals, and air pollution [5]. The major factor contributing to air pollution due to vegetation burning is the addition of $\mathrm{CO}_{2}$ to the environment. Species related to a fire-prone environment positively respond to smoke produced during fire in the forest [6]. Plant-derived smoke enhanced the germination process in various plant communities such as the South African Mediterranean $[7,8]$ and Californian chaparral $[9,10]$. Compounds in smoke are stable at high temperatures, water soluble, and very active even at low concentrations [11]. The long-lasting effectiveness of plant-derived smoke solution ruled out the uncertainty about its storage period and made it more worthy in terms of its in-time availability. 
Plant-derived smoke was proven to be a promoting factor for several growth-related phenomena of plants including breaking seed dormancy, accelerating seed germination, and increasing seedling vigor [12]. Biochemical parameters such as photosynthetic pigments, total nitrogen, total soluble proteins, and photosynthetic rates increased under plant-derived smoke treatments [13]. Furthermore, a supply of plant-derived smoke solutions during flooding stress led to the flooding recovery of soybean after the removal of water [14]. It reduced the inhibitory effects of heavy metal, drought, salinity, and high/low temperature stresses on plant growth [15]. These results indicated that plant-derived smoke is a growth enhancer, reducer of inhibitory effect of environmental stresses, and a possible plant-growth fertilizer.

After the authentication of plant-derived smoke as an important germination cue and a positive growth regulator in various plant growth-related wonders [1,2], various arguments were made about the nature of smoke solution, different active compounds present in smoke, and the nature/mode of action of smoke. This review highlights the roles of plant-derived smoke in seed germination and plant growth, summarizes its role in physiological parameters of plants, and focuses on molecular aspects of plant responses towards smoke.

\section{Preparation of Plant-Derived Smoke}

Plant-derived smoke is prepared through various methods, which are convenient and economical to adopt. The most familiar way to produce plant-derived smoke solution is to bubble out the smoke through water to dissolve the biologically active compounds of smoke in water. Smoke was generated in a drum and bubbled through distilled water using compressed air. After dilution, this smoke extract was applied to seeds of various plant species resulting in improved seed germination. Based on this method, a wide range of plant materials were used to prepare aqueous smoke extracts [16]. All plant materials are generally suitable for preparation of smoke extracts [17]. A concentrated aqueous smoke extract can be diluted with water.

The active compounds in smoke are not carried far in smoke. These compounds condense as the smoke cools and remain close to the fire site [18]. The method was further calculated using a standard weight of the semi-dried plant material weighing $333 \mathrm{~g}$ burnt in chimney, using an electric heater. Smoke was produced and passed through a beaker with $1 \mathrm{~L}$ distilled water in order to obtain a concentrated form of smoke solution. The concentrated plant-derived smoke was filtered (Figure 1). This standard concentrated smoke solution was used in various dilutions in different studies. The variable effect of plant-derived smoke solution in different dilutions is an interesting factor. It is assumed, that due to presence of numerous compounds in plant-derived smoke solution, the concentration balance among these compounds is important and is specific for each plant species. This might be the reason that different plants show optimum growth response at different dilutions which support our assumption.

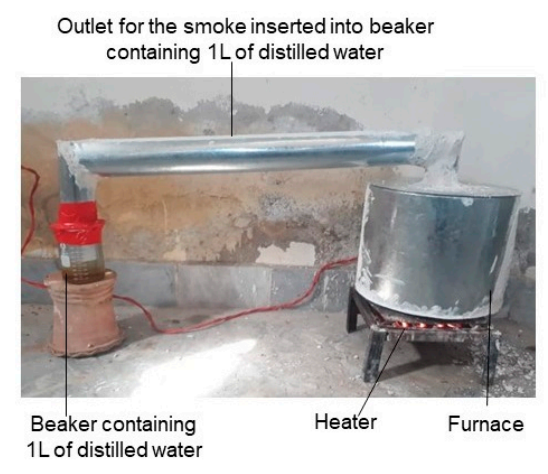

Figure 1. Preparation of plant-derived smoke solution. Plant material is burnt in the specified chamber through an electric heater. The smoke coming from burning plant material is collected through a pipe by bubbling this smoke into $1 \mathrm{~L}$ distilled water at the other end of pipe. All the setup is completely sealed to avoid any smoke escape. 


\section{Components in Plant-Derived Smoke}

Plant-derived smoke is a complex mixture of compounds derived from burning a natural mixture of plant species and stimulates seed germination and plant growth from a wide range of plants. As compounds in plant-derived smoke, butanolide known as karrikins and cyanohydrin are the active compound (Table 1 and Figure 2). The active compounds in plant-derived were separated from different plants, showing the diverse nature of smoke based on the plant used to produce smoke. These compounds set the base that why different plants respond to plant-derived smoke differently.

Table 1. A list of different compounds identified in plant-derived smoke.

\begin{tabular}{ccc}
\hline Plant Source for Plant-Derived Smoke & Identified Compounds & References \\
\hline Lettuce & 1,8-cineole & {$[19]$} \\
Skilpadbessie; Red oat grass & 3-methyle-2-Hfuro [2,3-C]pyran-2-one (Butenolide) & {$[11]$} \\
Skilpadbessie; Red oat grass & 3,4,5-trimethylfuran-2(5H)-one & {$[20]$} \\
Red-and-green kangaroo paw & glyceronitrile, cyanohydrin & {$[21]$} \\
Coyote tobacco & Catechol & {$[22]$} \\
Ginkgo & Hydroquinone & {$[23]$} \\
Skilpadbessie & 5,5-dimethylfuran-2(5H)-one & {$[24]$} \\
Red oat grass & (5RS)-5-ethylfuran-2(5H)-one & {$[24]$} \\
\hline
\end{tabular}

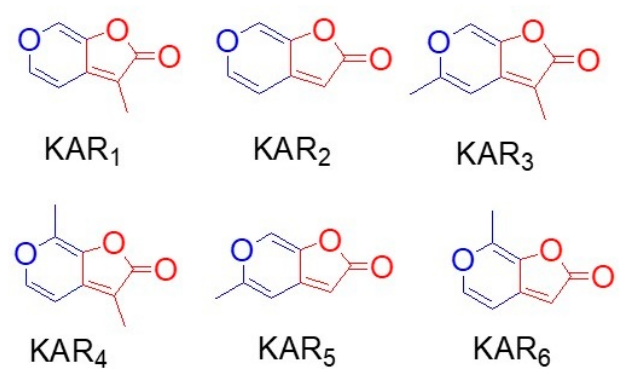

Figure 2. Chemical structures of karrikins family involved in seed germination. KAR1, KAR2, KAR3, KAR4, KAR5, and KAR6 were shown. All karrikins share the basic structure commonly with two ring structures: one is a six-membered heterocyclic pyran shown as blue and the other is a five-membered lactone ring as a butanolide shown as red.

\subsection{Karrikins}

After the discovery of plant-derived smoke as a vital germination agent [1], the active compound from burning filter paper and cellulose-derived smoke was identified using a bioassay-guided fractionation procedure which includes solvent partitioning, high-performance liquid chromatography, gas chromatography-mass spectrometry, and nuclear magnetic resonance $[11,25]$. This compound stimulated germination of different smoke-responsive species from various regions including Australia, North America, and South Africa [26]. The structure of the promoting compound was confirmed by chemical synthesis as 3-methyl-2H-furo[2,3-c] pyran-2-one (Figure 2) [11] which was a class of compounds containing a butenolide (a four-carbon lactone) fused to a pyran ring. This compound was named as karrikinolide (KAR1). It was active at very low concentrations even down to $10^{-10} \mathrm{M}$ [11]. Structurally, karrikins (butenolide) consist of a five-membered butenolide ring fused to a six-membered pyran ring (Figure 2). They are different with respect to methyl substitutions, in which KAR1 and KAR3 are the most active for stimulating seed germination [27]. Various analogs of karrikins were synthesized by substitutions at carbons 3,4 , and 7 [25,28-30]. The activities of these analogs were also evaluated on highly smoke-responsive species including lettuce, which clarified that plant responses to various analogs varies [27]. These analyses were performed at seed germination level; however, extending these investigations to post-germination stages would further clarify which analog is most suitable for the optimum response of a specific bioactivity. 
Karrikins trigger the germination of numerous species from fire-prone [31], fire free [32], and agricultural environments [3,25]. Besides having promoting effects on seed germination, karrikinolides are phytoreactive compounds with applications in horticulture, ecological restoration, and agriculture [31]. Plant-derived smoke significantly enhanced the wheat seedling growth with a remarkable increase in leaf area, lengths, and fresh weights of root and shoot in wheat [33]. Smoke-water-treated tomato seedlings exhibited a remarkable increase in growth and yield [34]. Seedling mass was reported to be enhanced by smoke treatment in lettuce and cucumber $[17,35]$. Plant-derived smoke showed a promoting effect on edible banana by increasing the number of shoots [36], while, in onion, number, length and mass of leaves, and bulb diameter and weight was also increased in response to smoke treatment [35]. Growth enhancement in horticultural crops suggested the possible use of smoke technology for cultivation and improvement of these crops. Cytotoxic and genotoxic effects of smoke-water were evaluated with five strains of Salmonella typhimurium marking it safe at the concentrations tested between $1 \times 10^{-4}$ and $3 \times 10^{-10} \mathrm{M}$ [37]. Moreover, in addition to promote the early growth, KAR1 enabled the tomato plants to tolerate temperature stress [38]. A significant improvement in the adverse effects of salt stress was observed in smoke-treated maize seedlings [39]. Salt tolerance was attributed to increased activities of antioxidants, increased level of $\mathrm{K}^{+}$ and $\mathrm{Ca}^{+2}$, while the $\mathrm{Na}^{+}$content was reduced in smoke-treated maize under salt stress [39]. A similar trend of stress alleviation was observed in smoke primed rice seedlings under salt stress. In addition to previously discussed parameters, alleviation was further supported by increase in cell membrane stability of smoke primed rice seedlings compared to non-treated ones [40]. Furthermore, flooding stress tolerance [14] and reduction in the inhibitory effects of heavy metals on plant growth [15] are also well documented. This characteristic can be interpreted as plant-derived smoke is not only responsible for promoting plant growth but also strategically involved in protecting plants against abiotic stresses.

\subsection{Other Components}

Another major germination stimulant was isolated from plant-derived smoke known as cyanohydrin (Table 1). Several related cyanohydrins such as mandelonitrile, acetone cyanohydrin, glycolonitrile, and 2,3,4-trihydroxybutyronitrile are present and stimulated seed germination of different plant species. The activities of these compounds are due to the spontaneous release of cyanide, suggesting an ecological role for cyanide in the post-fire revival of plant communities [21]. It was suggested that cyanide signaling interacts with the reactive oxygen species, and their effect might be linked with an obvious increase in hydrogen peroxide and superoxide anion generation [41]. Cyanide-stimulated germination is common in a wide variety of plant species [21]. The novelty of discovering cyanohydrins in smoke establishes the cyanide as an important germination stimulant in post-fire environments [21]. This clue is further strengthened by the fact that chemical compounds must be added and remain in the soil for an appropriate period for their effectiveness in post-fire environment. Cyanohydrins have a suitable time of persistence in the top layers of the soil where most of the dormant seeds are present, so they are timely available as a growth promoting signal [21]. Taking together these details, it is comprehended that further investigations are yet to be performed for more output in the form of new compounds in plant-derived smoke for its more valid implementation as growth regulator.

On the other hand, some of the compounds which are present in higher concentrations in smoke solution have inhibitory effects on plant growth [42], such as 3,4,5-trimethyl-2(5H)-furanone found in smoke solution, which inhibited seed germination [20]. This germination inhibitor is commonly present in plant-derived smoke and significantly reduced the germination-promoting nature of KAR1 [20]. The inhibitory effects of 3,4,5-trimethyl-2(5H)-furanone are only reported in lettuce seeds [20]. Furthermore, inhibitory compounds, 5,5-dimethylfuran-2(5H)-one and (5RS)-5-ethylfuran-2(5H)-one, are isolated from skilpadbessie and red oat grass-derived smoke solution, respectively [24]. To date, various compounds have been identified in plant-derived smoke (Table 1). The presence of various compounds reflects that seed cueing by plant-derived smoke is controlled by various agents; each affects 
the germination and growth response differently. This diverse chemistry of plant-derived smoke might be the reason behind its broad spectral impact on various growth responses of plants.

\subsection{Plant-Derived Smoke as Biostimulant}

Bio means life and stimulant means to enhance. Based on the available scientific literature and materials dedicated to this term, the biostimulants are defined as the substances (derived from living organisms by their death/decay or burning) or microorganisms that are applied to seeds, soil, plants, or on rhizosphere resulting in the stimulation of natural processes to enhance the plant quality and yield through nutrient uptake, nutrient use efficiency, and tolerance to abiotic stress [43]. In other words, biostimulants are all those products that reduce the need for synthetic fertilizers and increase plant growth and tolerance to abiotic stresses. These substances are efficient in small concentrations, favoring an efficient performance of bioactivities thus leading to high yields and good quality products. These substances offer a potentially new strategy for the regulation of physiological processes in plants leading to enhanced growth and mitigation of abiotic stresses. Keeping in view the definition, effect, and association with enhanced plant growth and stress tolerance, plant-derived smoke has recently been discussed as a "Biostimulant" [44]. Along with other molecules with biostimulant characteristics, smoke water and karrkins were used to promote the cultivation of Amaranthus hybridus and resulted in an increased length and fresh weight of root and shoot; increased number of leaves, total leaf area, and stem thickness as compared to non-treated plants. Protein, carbohydrate, and chlorophyll contents were also increased in response to these biostimulants, clearly emphasizing their use in agriculture. In the continuation of this research, [45] reported that among all the tested biostimulants, smoke water showed maximum enhancement of seed germination percentage in the dark. Furthermore, they suggested plant-derived smoke as the best organic biostimulant for the potential application to improve seed germination and growth of Cleome gynandra.

The role of plant-derived smoke in inducing abiotic-stress tolerance makes it further fit into the category of biostimulants. Among the various roles of plant-derived smoke in plant growth $[25,31-34,37,38]$, the induction of stress tolerance that includes alleviation of salt stress in rice and maize [13,39], heat stress in tomato [38], flooding stress in soybean [14], and reversion of abscisic acid stress in lettuce [46] has highly validated its candidature as a biostimulant.

\section{Effect of Plant-Derived Smoke on Dormancy Releasing, Seed Germination, and Seedling Growth}

The majority of the research work performed on plant-derived smoke is conducted on morphological aspects of seed germination and plant growth. These investigations are about the smoke-solution effects on seed dormancy, seed germination, seedling length, and biomass. Various reports clarified that although plant responses towards smoke vary greatly, they share few common responses. This variety of responses could also be interpreted in terms of the diverse nature of chemical compounds present in smoke and their mode of application on plants. Smoke or the derived active compounds from smoke significantly enhanced germination, seedling vigor, and seedling mass of large number of plant species (Table 2, Table S1). 
Table 2. Effect of plant-derived smoke on seed germination and plant-growth responses of various plant (2010-2020).

\begin{tabular}{|c|c|c|}
\hline Experimental Plant Species & Major Findings & Ref. \\
\hline \multicolumn{3}{|c|}{ Smoke solution for application } \\
\hline Lantana & $\begin{array}{l}\text { Seed germination, germination velocity index } \\
\text { and vigor index increased }\end{array}$ & [47] \\
\hline Dyer's woad & Seedling mass increased & [48] \\
\hline Rock rose & Germination percentage increased & [49] \\
\hline Edible banana & $\begin{array}{l}\text { Seedling length, seedling mass, number of } \\
\text { shoots, number of roots, number of leaves, } \\
\text { leaf area increased }\end{array}$ & [36] \\
\hline Plant species from grassland & Seed germination increased & {$[50]$} \\
\hline Pawpaw & $\begin{array}{l}\text { Seed germination rate, seedling length and } \\
\text { vigor, and number of leaves increased }\end{array}$ & [51] \\
\hline Canola & Plant regeneration, seedling length increased & [52] \\
\hline Mediterranean Basin flora & Seedling emergence was promoted & {$[53]$} \\
\hline Society garlic., Wild garlic & $\begin{array}{l}\text { Seed germination, seedling mass, root length } \\
\text { and root number increased }\end{array}$ & [54] \\
\hline $\begin{array}{c}\text { Lavandula stoechas,Origanum onites, } \\
\text { Phlomis bourgaei, Stachys cretica, Satureja } \\
\text { thymbra, Teucrium lamiifolium }\end{array}$ & Seed germination increased & [55] \\
\hline Coyote tobacco., Whispering bells & Germination percentage increased & [56] \\
\hline Sweet potato & $\begin{array}{l}\text { Number of adventitious roots, length of } \\
\text { adventitious roots and length of lateral } \\
\text { roots increased }\end{array}$ & [57] \\
\hline Millet & $\begin{array}{l}\text { Seed germination, seedling length and } \\
\text { seedling mass were enhanced }\end{array}$ & [58] \\
\hline Carrot & Seed germination, seedling length increased & [59] \\
\hline Barnyard grass & $\begin{array}{l}\text { Germination percentage, relative root } \\
\text { elongation, seedling length and seedling mass } \\
\text { were promoted }\end{array}$ & {$[60]$} \\
\hline Perennial forage species & Seed germination increased & {$[61]$} \\
\hline 12 eastern Mediterranean basin plants & Seed germination increased & {$[62]$} \\
\hline 10 Interior West Penstemon species & Seed germination increased & [63] \\
\hline Canadian horseweed & Seed germination, seedling growth increased & {$[64]$} \\
\hline Wheat & $\begin{array}{l}\text { Germination percentage, germination index, } \\
\text { seedling vigor index and seedling length } \\
\text { increased }\end{array}$ & [33] \\
\hline Helianthemum tinetense & Seed germination increased & [65] \\
\hline Astragalus verus, Bromus tectorum & Seed germination increased & [66] \\
\hline Mediterranean Basin flora & Seed germination increased & [67] \\
\hline Wild oat & $\begin{array}{l}\text { Germination percentage and per unit weight } \\
\text { water content increased, coat rupturing } \\
\text { was stimulated }\end{array}$ & [68] \\
\hline Shortgrass Prairie species & Seed germination increased & [69] \\
\hline Mediterranean plant species & $\begin{array}{l}\text { Seed germination and seedling length } \\
\text { were enhanced }\end{array}$ & {$[70]$} \\
\hline
\end{tabular}


Table 2. Cont

\begin{tabular}{|c|c|c|}
\hline Experimental Plant Species & Major Findings & Ref. \\
\hline Rice & $\begin{array}{l}\text { Root length and root fresh/dry } \\
\text { weights increased }\end{array}$ & [15] \\
\hline Cape flats sand Fynbos species & $\begin{array}{l}\text { Seedling length and seed germination } \\
\text { were promoted }\end{array}$ & [71] \\
\hline Wheat & $\begin{array}{l}\text { Root/shoot length, root fresh/dry weight, } \\
\text { shoot fresh/dry weight and leaf } \\
\text { area increased }\end{array}$ & [33] \\
\hline Lupinus angustifolius & Seed germination increased & [72] \\
\hline Chickpea & $\begin{array}{l}\text { Seed germination, seedling length and } \\
\text { mass increased }\end{array}$ & [73] \\
\hline Maize & $\begin{array}{l}\text { Seed germination, seedling length and } \\
\text { mass increased }\end{array}$ & [74] \\
\hline $\begin{array}{l}\text { Tomato, Cucumber, Pot marigold, } \\
\text { Sword lily }\end{array}$ & $\begin{array}{l}\text { Seed germination percentage/rate, } \\
\text { seedling length and fresh } \\
\text { weight increased }\end{array}$ & [35] \\
\hline Lettuce & $\begin{array}{l}\text { Seed germination percentage } \\
\text { was promoted }\end{array}$ & [75] \\
\hline Calotropis gigantea & Seed germination increased & [76] \\
\hline Rice & $\begin{array}{l}\text { Seed water uptake and germination } \\
\text { percentage were enhanced }\end{array}$ & [77] \\
\hline \multicolumn{3}{|c|}{ Trimethylebutenolide analogs and butenolide solution } \\
\hline $\begin{array}{l}\text { Lettuce., Whispering bells., Tomato } \\
\text { bush }\end{array}$ & Germination percentage increased & [29] \\
\hline Lettuce & Germination percentage increased & [78] \\
\hline Lettuce & Germination percentage increased & [79] \\
\hline Tangle head & Germination percentage increased & [80] \\
\hline Lettuce & $\begin{array}{l}\text { Seed germination percentage } \\
\text { was promoted }\end{array}$ & [81] \\
\hline \multicolumn{3}{|c|}{ Smoke and butenolide solution } \\
\hline onion & $\begin{array}{l}\text { Number of leaves, leaf length, leaf weight, } \\
\text { bulb diameter and bulb weight increased }\end{array}$ & [35] \\
\hline Melon & Seedling mass increased & [82] \\
\hline Button creeper & $\begin{array}{l}\text { Seed germination increased, and seed } \\
\text { dormancy broke }\end{array}$ & [83] \\
\hline Asian mustard & Germination percentage increased & [84] \\
\hline Tropical soda apple & $\begin{array}{l}\text { Seed germination, seedling length and } \\
\text { mass increased }\end{array}$ & [85] \\
\hline $\begin{array}{c}\text { Wild oat, Wimmera ryegrass, Weeping } \\
\text { lovegrass, Little seed canary grass, } \\
\text { Barley grass, Perrenial veldgrass, } \\
\text { Ripgut brome }\end{array}$ & Germination percentage increased & [86] \\
\hline Edible banana & $\begin{array}{l}\text { Leaves number, branching, seedling } \\
\text { length, seedling weight and root } \\
\text { number increased }\end{array}$ & [87] \\
\hline Tree aloe & $\begin{array}{l}\text { Seed germination and seedling } \\
\text { growth increased }\end{array}$ & [88] \\
\hline Torch lily, Opal flower & $\begin{array}{l}\text { Pollen germination and pollen tube } \\
\text { growth was enhanced }\end{array}$ & [89] \\
\hline
\end{tabular}


Table 2. Cont.

\begin{tabular}{|c|c|c|}
\hline Experimental Plant Species & Major Findings & Ref. \\
\hline Kikuyu grass & $\begin{array}{l}\text { Seedling vigor, seedling mass, and leaf } \\
\text { number increased }\end{array}$ & [90] \\
\hline Okra & Seedling length increased & [91] \\
\hline Lettuce & $\begin{array}{l}\text { Seed germination and radicle } \\
\text { length increased }\end{array}$ & [92] \\
\hline \multicolumn{3}{|c|}{ Glyceronitrile and smoke/butanolide solution } \\
\hline $\begin{array}{l}\text { Kangaroo paw., Gyrostemon, } \\
\text { Racemigerus, Gyrostemon ramulosus }\end{array}$ & $\begin{array}{l}\text { Seed germination and seedling length } \\
\text { were enhanced }\end{array}$ & [93] \\
\hline Kangaroo paw & $\begin{array}{l}\text { Seed germination and embryo } \\
\text { growth increased }\end{array}$ & [94] \\
\hline Mediterranean plant species & $\begin{array}{l}\text { Seed germination and seedling length } \\
\text { were enhanced }\end{array}$ & [70] \\
\hline \multicolumn{3}{|c|}{ Aerosol smoke and smoke solution } \\
\hline Arabidopsis & $\begin{array}{l}\text { Seed germination and hypocotyl length } \\
\text { increased; and seed dormancy was broken }\end{array}$ & {$[95,96]$} \\
\hline \multicolumn{3}{|c|}{ Smoke and PGPR solution } \\
\hline Rice & $\begin{array}{l}\text { Seed germination and shoot/root } \\
\text { lengths increased }\end{array}$ & {$[97]$} \\
\hline
\end{tabular}

\subsection{Seed Germination}

Smoke is a germination cue, and its positive effects are reported on different plant species belonging to genera and families of gymnosperms and angiosperms [98], commercial crops, and different medicinal plants [99]. Seed germination is a phenomenon in which an embryo present within the seed grows into a seedling and subsequently a plant. Various approaches have been used demonstrating the promoting effects of plant-derived smoke solution in enhancing seed germination, breaking seed dormancy, and subsequent growth processes. Explaining the possible reason involving this germination promoting and breaking seed dormancy phenomenon, it was reported that plant-derived smoke tends to induce the activity of amylase, and increase DNA replication and $\beta$-tubulin accumulation before the radicle protrusion of dormant oat caryopses, thus leading to the aforementioned processes [68]. Following similar mechanism to increase the seed germination, the positive effect of plant-derived smoke on various crops such as maize [3,12,100], rice [13,101], and wheat [102] has been clarified.

Plant-derived smoke broke seed dormancy of California chaparral plants [10], 7 species from South Western Australia [103], Apium graveolens [104], and wild oat [105]. Scarifications by using smoke enhanced the number and size of spreading channels in the cuticle of seeds [10]. Using a transcriptomic technique, a study on molecular aspects of seed germination in lettuce reported that abscisic acid, seed maturation, and dormancy-related transcripts were up-regulated by trimethyl butenolide and suppressed by KAR1 [106]. This study clarified that increased seed germination by KAR1 might be due to suppression of abscisic acid and dormancy-related transcripts by KAR1 present in smoke. Another investigation explaining the physiology of breaking seed dormancy in response to smoke water and KAR1 treatment was carried out by Gupta et al. [81]. It was demonstrated that smoke water and KAR1 significantly promoted the lettuce seed germination by reducing abscisic acid level and increasing the activity of hydrolytic enzymes, which supports the mobilization of stored food reserves. Although these observations are in accordance with that of Plazek et al. [72] the response mechanism of arabidopsis towards karrikins presented a somewhat different picture with independence of the abscisic acid level and requiring gibberellic acid synthesis and light [107]. The findings from these studies indicated that the response mechanism of plants towards smoke and 
smoke-derived compounds may vary from plant to plant. It is also reflected that plant-derived smoke not only affects the absolute concentrations of growth relating hormones but affects the fate of various physiological processes by interfering with the comparative ratio among these growth regulators that might lead to breaking seed dormancy and promoting seed germination.

\subsection{Post-Germination Responses of Plant Towards Plant-Derived Smoke}

Plant-derived smoke solution has post-germination effects. Smoke solution has positive effects on seedling development, seedling vigor, seedling length, seedling mass, and crop yield of different plants-including celery [104], okra [108], Acacia [109]; seedling emergence of the mesic grassland in South Africa [79]; tomato [110]; germination of Lamiaceae Mediterranean plants, slime lilies, and blouberglelie [55]. It has positive effect on root initiation of mung bean [111], tomato [110], and pollen germination and pollen tube growth of different plants [89], seedling length of Brazilian savannas [112], seedling fresh weight of perennial forage species [83], and somatic embryogenesis of tassel rope-rush [113].

Positive effects of plant-derived smoke solution at post-germination growth were observed in rice $[13,114,115]$, wheat [102], and maize [3,12]. These reports clarified that stimulatory effects of smoke continue in post-germination stages and may enhance the biomass of the plants. The post-germination studies of smoke-treated seeds elucidate that although smoke treatment may not affect the germination stage, it still may promote growth at the post-germination stage [75]. It is, therefore, recommended to extend all germination studies necessarily up to the seedling stage so that the post-germination effects of plant-derived smoke can be interpreted.

\section{Physiological Responses of Plant to a Plant-Derived Smoke}

Plant responses to plant-derived smoke at the physiological level have been assessed for various plants. Although physiological and biochemical attributes of plants may vary from plant to plant and based on the mode of application of smoke to plants; however, they also share various responses in common. Here, various modes of smoke application on different plants and plant responses are described in detail. Several plants including maize, wheat, rice, and tomato exhibited an increased growth and vigor in response to plant-derived smoke (Table 3).

Table 3. Effect of plant-derived smoke on physiological responses of various plants.

\begin{tabular}{|c|c|c|}
\hline Mode of Smoke/Smoke Compounds Application & Major Findings & Ref. \\
\hline \multicolumn{3}{|c|}{ Tomato } \\
\hline Seed imbibition in Butenoloides solution & $\begin{array}{l}\text { Total soluble proteins in embryo, } \\
\text { cotyledons and seedlings increased }\end{array}$ & [116] \\
\hline Smoke and butenolide solution & $\begin{array}{l}\text { Ascorbic acid, b-carotene, lycopene and } \\
\text { total soluble solids increased }\end{array}$ & [34] \\
\hline $\begin{array}{l}\text { Smoke solution prepared from different } \\
\text { plants species }\end{array}$ & $\begin{array}{l}\alpha \text {-amylase activity and abscisic acid content, } \\
\mathrm{N}, \mathrm{P} \text {, and K ion contents, chlorophyll } \\
\text { contents increased }\end{array}$ & [35] \\
\hline \multicolumn{3}{|c|}{ Rice } \\
\hline Seed priming in smoke solution & $\begin{array}{l}\text { Proline contents, photosynthetic } \\
\text { pigments increased }\end{array}$ & [101] \\
\hline Seed priming in smoke solution & $\begin{array}{l}\text { Ion contents, cell membrane stability, } \\
\text { protein contents, total nitrogen } \\
\text { contents increased }\end{array}$ & [115] \\
\hline \multicolumn{3}{|c|}{ Wheat } \\
\hline
\end{tabular}


Table 3. Cont.

\begin{tabular}{|c|c|c|}
\hline Mode of Smoke/Smoke Compounds Application & Major Findings & Ref. \\
\hline Smoke solution & $\begin{array}{l}\text { Electrolyte }\left(\mathrm{Na}^{+2}, \mathrm{Ca}^{+2}, \mathrm{~K}^{+}\right) \text {contents, } \\
\text { nitrogen and protein contents, total soluble } \\
\text { sugar, total soluble proteins, proline } \\
\text { contents, glycine betaine, antioxidant } \\
\text { enzymes increased }\end{array}$ & [33] \\
\hline Smoke and PGPR solution & $\begin{array}{l}\text { Photosynthetic pigments, Electrolyte }\left(\mathrm{Na}^{+2} \text {, }\right. \\
\left.\mathrm{Ca}^{+2}, \mathrm{~K}^{+}\right) \text {content, semyzne tnadixoitna, } \\
\text { enilorp, stnetnoc nietorp, ragus } \\
\text { elbulos latotdesaercni }\end{array}$ & [102] \\
\hline Smoke solution & $\begin{array}{l}\text { Carbohydrate, protein and lipid analysis, } \\
\text { macro and micro elements } \\
\text { concentrations increased }\end{array}$ & [33] \\
\hline \multicolumn{3}{|c|}{ Wild garlic } \\
\hline Smoke solution & $\begin{array}{l}\text { Flavonoids, total phenolics, condensed } \\
\text { tannins were regulated }\end{array}$ & [54] \\
\hline \multicolumn{3}{|c|}{ Dyer's woad } \\
\hline Smoke solution & Indigo concentration increased & [48] \\
\hline Smoke solution & $\begin{array}{l}\text { Photosynthetic yield, chlorophyll } \\
\text { fluorescence increased }\end{array}$ & [117] \\
\hline \multicolumn{3}{|c|}{ Kikuyu grass } \\
\hline Smoke and butenolide solution & Cd uptake decreased & [90] \\
\hline \multicolumn{3}{|c|}{ Pawpaw } \\
\hline Smoke solution & $\begin{array}{l}\text { Nitrogen, Ion contents, } \mathrm{Fe}, \mathrm{Zn}, \mathrm{Cu} \text {, } \\
\text { chlorophyll content increased }\end{array}$ & [51] \\
\hline \multicolumn{3}{|c|}{ Tree aloe } \\
\hline Smoke and butenolide solution & Flavonoids, total phenolics were regulated & [88] \\
\hline \multicolumn{3}{|c|}{ Bone seed } \\
\hline Aerosol smoke solution application & $\begin{array}{l}\text { Stomatal conductance, } \mathrm{CO}_{2} \text { assimilation } \\
\text { rate and intercellular } \mathrm{CO}_{2} \text { levels increased }\end{array}$ & [118] \\
\hline \multicolumn{3}{|c|}{ Edible banana } \\
\hline Smoke and karrikinolide (butenolide) solution & $\begin{array}{l}\text { Photosynthetic pigments, total phenolics, } \\
\text { total flavonoids, } \\
\text { proanthocyanidins increased }\end{array}$ & [36] \\
\hline \multicolumn{3}{|c|}{ Ear-leaf nightshade, Talinum, Asthma-weed, Catsear, Akmella } \\
\hline $\begin{array}{c}\text { Smoke, butanolide and } \\
\text { trimethylebutanolide solution }\end{array}$ & $\alpha$ amylase activity increased & [119] \\
\hline \multicolumn{3}{|c|}{ Okra } \\
\hline $\begin{array}{l}\text { Smoke, butanolide and } \\
\text { trimethylebutenolide solution }\end{array}$ & $\begin{array}{l}\alpha \text { amylase activity and bacterial } \\
\text { abundance increased }\end{array}$ & [119] \\
\hline \multicolumn{3}{|c|}{ Maize } \\
\hline Smoke solution priming & $\begin{array}{l}\text { Ion contents, photosynthetic pigments and } \\
\text { antioxidant enzymes increased }\end{array}$ & [39] \\
\hline Smoke solution & $\begin{array}{l}\text { Chlorophyll pigments and total soluble } \\
\text { proteins increased }\end{array}$ & [12] \\
\hline \multicolumn{3}{|c|}{ Lettuce } \\
\hline Smoke solution & Total soluble sugar increased & [120] \\
\hline Smoke/butenolide/ trimethylebutanolide solution & $\begin{array}{l}\alpha \text { - amylase activity, starch, sugar, protein } \\
\text { contents, lipase activity and lipid } \\
\text { contents increased }\end{array}$ & [81] \\
\hline
\end{tabular}


Table 3. Cont.

\begin{tabular}{|c|c|c|}
\hline Mode of Smoke/Smoke Compounds Application & Major Findings & Ref. \\
\hline \multicolumn{3}{|c|}{ Barnyard grass } \\
\hline Smoke solution & $\begin{array}{l}\alpha \text { amylase and abscisic acid } \\
\text { contents increased }\end{array}$ & {$[60]$} \\
\hline \multicolumn{3}{|c|}{ Sword lily, Cucumber, Pot marigold } \\
\hline $\begin{array}{l}\text { Smoke solution prepared from different } \\
\text { plants species }\end{array}$ & $\begin{array}{l}\alpha \text {-amylase activity and abscisic acid content, } \\
\mathrm{N} / \mathrm{P} / \mathrm{K} \text { ion contents, and chlorophyll } \\
\text { contents increased }\end{array}$ & {$[80]$} \\
\hline \multicolumn{3}{|c|}{ Wild oat } \\
\hline Smoke solution & $\begin{array}{l}\alpha / \beta \text {-amylase activities, starch contents, } \beta \\
\text { tubulin accumulation increased }\end{array}$ & [68] \\
\hline \multicolumn{3}{|c|}{ Chickpea } \\
\hline Smoke solution & $\begin{array}{l}\text { Total soluble sugar, total soluble proteins, } \\
\text { number of rhizobia increased }\end{array}$ & [73] \\
\hline
\end{tabular}

\subsection{Pigments}

Enhancement of plant growth and development in response to smoke solution are dependent on better biochemical activities, which encourage vegetative and reproductive growth. Pigments play a key role in the photosynthesis process through which plants synthesize their organic food. Pigments capture sunlight energy and convert it to chemical energy through photosynthesis. Plant-derived smoke solution-treated seedlings are vigorous and healthy [121] resulting in more chlorophyll and improved photosynthetic activity. A significant increase in the relative abundance of various photosynthetic pigments was observed in smoke-treated wheat seedlings [33]. Synthesis/accumulation of chlorophyll a relative to chlorophyll $b$ increased in all the smoke treatments, resulting in increased efficiency of light reaction in plants. Plant-derived smoke solution increased biosynthesis of ribulose-1,5-bisphosphate carboxylase/oxygenase in chickpea and maize [73,74]. Smoke solution enhanced gaseous exchange, photochemical activities, and $\mathrm{CO}_{2}$ fixation which induced an increase in photosynthesis. An enhancement of maximum quantum efficiency, stomatal conductance, intercellular $\mathrm{CO}_{2}$ Concentration, and net photosynthesis was recorded in carrot [122]. These observations further prove that plant-derived smoke and smoke-derived compounds hold promising use in crop improvement in terms of photosynthetic products.

Smoke solution increased photosynthetic rate, transpiration rate, and stomatal conductance of dyer's woad seedlings, indicating that the treatments of smoke solution could enhance the stomatal opening [48]. Plant-derived smoke solution plays a role in stomatal opening, which may be a cause of increasing photosynthetic activity. Stomatal opening is mainly controlled by abscisic acid [123]. They measured the phytohormones concentrations in germinating soybean seedlings and reported that karrikins were responsible for altering the gibberellic acid/abscisic acid ratio. These reports support that the interaction of phytohormones with smoke water and KAR1 could be anticipated as a possible mode of action for stomatal opening and other smoke/karrikin-related growth responses [123]. In rice, smoke solution enhanced the amount of chlorophyll $a / b$ and total carotenoids with a key role in photosynthesis [13]. This increase in plant pigments enables them to harness more sunlight, thus resulting in the increased photosynthetic output of the plant. An increased response in photosynthetic pigment concentration has strengthened the fact that plant-derived smoke is equivalently active as other plant growth hormones, which take this route for plant growth promotion.

\subsection{Phenolic Compounds}

Phenolic compounds are important secondary metabolites playing a vital role in plant survival through protection against ultra-violet radiation [124], as signaling molecules $[125,126]$ and defense 
against plant herbivores and insects [127]. A higher concentration of flavonoids and total phenolic contents in plants shows more antioxidant activities [128]. Smoke solution and potassium application increased secondary metabolites (flavonoids and total phenolic contents) in medicinal plants [54]. Smoke solution up-regulated phenyl propanoid pathway and flavonoid-related genes, thereby enhancing phenolic biosynthesis [73,129]. Phenolics, flavonoids, and condensed tannins were significantly increased by plant-derived smoke solution in Wild garlic [54]. The level of phytochemicals in plants is often associated with resultant biological activities. The stimulatory effects of smoke solution on photo chemicals such as indigo, phenolics, and flavonoids in several other plant species have also been reported $[48,87,88]$. Besides phenolics contents, plant-derived smoke solution promoted the biosynthesis of protein by increasing absorption of growth nutrients [13].

Smoke significantly increased levels of nitrogen contents in roots and shoots of papaya [51] It was observed that application of nitrates enhanced seed germination in the fire annuals whispering bells and scorpion weed [130]. It was further assumed that oxidizing gases in smoke and acids generated on burnt sites might play a role in the germination of post-fire annuals in chaparral [131] Nitrate was suggested to be the principal factor inducing germination by acting as a nutrient and signal well [132]. It was inferred from the existing facts that in arabidopsis, a transcription factor acts downstream of nitrate signaling which induces nitrate-dependent gene expression. This regulation triggers a nitrate-induced decrease in abscisic acid that permits seed germination [132]. Plant-derived smoke affected various biochemical phenomena of plants resulting in the regulation of various growth parameters. Certainly, the regulation of all these growth phenomena is not as straight forward as it seems, and researchers investigating the role of smoke behind these mysteries should take heed of this.

\section{Molecular Mechanism in Plant of Plant-Derived Smoke}

Exploring the molecular mechanism of plant-derived smoke solution involved several attempts to unravel the mystery behind its mechanism of action on various plant-growth processes. Plant-growth processes are controlled by various signaling molecules, which may act singly or in coordination with other molecules endogenously and exogenously, and resulted in a variety of responses. As previously discussed, the mystery as to whether plant-derived smoke is of a diverse nature and composed of a variety of compounds makes the response mechanism of plants towards smoke more complicated and diverse. Molecular studies of plants treated with smoke solution started recently and are helpful in understanding the mode of smoke solution action (Table 4).

Table 4. Summary of molecular analyses of various plants exposed to karrikins/butenolides and plant-derived smoke.

\begin{tabular}{clc}
\hline Smoke Compounds & \multicolumn{1}{c}{ Major Findings } & Ref. \\
\hline Smoke solution & \multicolumn{1}{c}{$\begin{array}{c}\text { Lettuce } \\
\text { Genes related to germination, cell wall expansion, } \\
\text { translation, cell division cycle, carbohydrate metabolism } \\
\text { and abscisic acid regulation were regulated }\end{array}$} & [133] \\
\hline \multirow{2}{*}{ KAR1, trimethylbutenolide } & $\begin{array}{l}\text { Abscisic acid, seed maturation and dormancy-related } \\
\text { transcripts were up-regulated by trimethylbutenolide } \\
\text { and suppressed by KAR1 }\end{array}$ & [106] \\
\hline Smoke solution & \multicolumn{1}{c}{ Maize } & \\
\hline Smoke solution, KAR1 & Stress- and abscisic acid-related genes were up-regulated & [134] \\
\hline & $\begin{array}{l}\text { Smoke-water enhanced the ubiquitination of proteins } \\
\text { and activated protein-degradation-related genes. KAR1 } \\
\text { up regulated aquaporin gene }\end{array}$ & [135] \\
\hline
\end{tabular}


Table 4. Cont.

\begin{tabular}{|c|c|c|}
\hline Smoke Compounds & Major Findings & Ref. \\
\hline Smoke solution & $\begin{array}{l}\text { Sucrose synthase-, nucleotides-, signaling-, and } \\
\text { glutathione-related proteins increased; cell wall-, lipid-, } \\
\text { photosynthesis-, and amino acid degradation-related } \\
\text { proteins decreased }\end{array}$ & [74] \\
\hline \multicolumn{3}{|c|}{ Arabidopsis } \\
\hline Karrikins & $\begin{array}{l}\text { Karrikin signaling is F-box protein (MAX2) dependent. } \\
\text { Seed germination and seedling photomorphogenesis } \\
\text { was triggered by karrikin }\end{array}$ & [96] \\
\hline Karrikins & $\begin{array}{l}\text { Photosynthesis, carbohydrate metabolism, redox } \\
\text { homeostasis, transcription control, protein transport, } \\
\text { processing, protein degradation were regulated }\end{array}$ & [136] \\
\hline \multicolumn{3}{|c|}{ Salmonella typhimurium } \\
\hline $\begin{array}{l}\text { Smoke solution, } \\
\text { 3,7-dimethyl-2H-furo[2,3-c] } \\
\text { pyran-2-one }\end{array}$ & $\begin{array}{l}\text { No genotoxicity from smoke solution and smoke } \\
\text { isolated compounds }\end{array}$ & [137] \\
\hline \multicolumn{3}{|c|}{ Tomato } \\
\hline Butenolides & $\begin{array}{l}\text { Butenolides changed the DNA, RNA and protein } \\
\text { profiles, no effect on integrity of DNA }\end{array}$ & [116] \\
\hline \multicolumn{3}{|c|}{ Chickpea } \\
\hline Smoke solution & $\begin{array}{l}\text { Signaling-, nitrate pathway-, and transport-related } \\
\text { proteins increased. Protein metabolism-, cell-, and cell } \\
\text { wall-related proteins decreased }\end{array}$ & [73] \\
\hline \multicolumn{3}{|c|}{ Soybean } \\
\hline Smoke solution & $\begin{array}{l}\text { Protein abundance and gene expression of } \\
\text { O-fucosyltransferase family proteins increased, while } \\
\text { that of peptidyl-prolyl cis-trans isomerase and } \\
\text { Bowman-Birk proteinase isoinhibitor D-II decreased, } \\
\text { sucrose/starch metabolism and glycolysis } \\
\text { were suppressed }\end{array}$ & [14] \\
\hline Smoke solution & $\begin{array}{l}\text { Proteins related to protein synthesis, arginine } \\
\text { metabolism and ubiquitin-proteasome pathway were } \\
\text { regulated; metabolites related to amino acid, carboxylic } \\
\text { acids, and sugars were mostly altered }\end{array}$ & [138] \\
\hline Smoke solution & $\begin{array}{l}\text { Protein metabolism-, stress-, redox-, and mitochondrial } \\
\text { electron transport chain-related proteins were regulated }\end{array}$ & [139] \\
\hline \multicolumn{3}{|c|}{ Red sage } \\
\hline KAR1 & Production of tanshinone-I increased & [140] \\
\hline
\end{tabular}

\subsection{Karrikins Signaling and Changes at Transcription Level}

A differential expression of several expressed sequence tags related to germination, cell wall expansion, translational regulation, cell-division cycle, metabolism of carbohydrates, and regulation of abscisic acid was observed in smoke-treated lettuce [133]. Further validation of results using Real-time polymerase chain reaction presented that smoke treatment upregulated the transcript abundance of the genes, short-chain dehydrogenase/reductase, and late embryogenesis abundant protein as compared to control achenes kept in the light. Extending these investigations to maize, it was observed that smoke induced abscisic acid and other stress-related responses at the post-germination phase [134] which may result in a better adaptation to abiotic stresses. A microarray analysis was carried out in Arabidopsis seeds imbibed with KAR1, which resulted in an increased expression of light-induced 
genes revealing that karrikins have a role in priming light responses in the growing seedling [95] Smoke solution increased the protein ubiquitination; however, KAR1-treated kernels showed different response where an aquaporin gene was up-regulated [135]. The diversity in plant responses towards smoke and karrikins is interpreted as karrikins only make up a part of the whole chemistry of smoke, which contains karrikins along with thousands of other compounds whose effects are yet to be investigated.

The mechanism of karrikin action was established in Arabidopsis [141]. It was demonstrated that KAR1 is perceived by its receptors, the $\alpha / \beta$-hydrolase KAI2 (Karrikin Insensitive 2), resulting in a conformational change in KAI2. Consequently, the activated KAI2 enhances interaction with MAX2 (MORE AUXILLARY GROWTH2), which is an F-box protein. This results in the establishment of a Skp-Cullin-F-box (SCF) ubiquitin ligase complex comprising SMAX1 (SUPPRESSOR OF MAX2 1). SMAX1is considered as a putative substrate in the KAI2-SCFMAX2 complex, which is degraded in $26 \mathrm{~S}$ proteasome after polyubiquitination. Using crystallographic techniques and ligand-binding experiments for KAI2 recognition of karrikins, it was revealed that parts of the KAI2-KAR1 complex seem to adjust KAI2 interactions to the downstream component of the karrikin-signaling pathway [141]. The mutual usage of site-directed mutagenesis, protein X-ray crystallography, and active binding measurements is evident, which makes KAI2 fit inside the signal transduction pathway of smoke/KAR1. The studies about the seeds of KAI2 mutants were unaffected by KAR1 $[96,142]$ representing that KAI2 is essential for KAR1 perception. However, conformational alteration occurs in KAI2 at the entrance of the active position due to the KAR1 binding [141]. A crevice of hydrophobic residues linking the polar edge of KAR1 and the helical domain insert suggests that KAI2-KAR1 generates an adjacent interface for binding signaling in a ligand-reliant way.

\subsection{Karrikins Signaling Pathway}

Strigolactones are plant hormones that hinder shoot branching. D14 (DWARF 14) hinders rice tillering and is a candidate in the branch-inhibition pathway, whereas the close homologue D14L (DWARF 14-LIKE) contributes in the signaling pathway of KARs [143]. Clearer marks are provided for the direct binding of SL to D14 and KAR to D14L using GR24 (a strigolactone analogue) and KAR1, respectively. The specific binding of these compounds was supported by the crystal structures of D14 and AtD14L, which show the central deep hydrophobic pockets capable of accommodating each ligand.

MAX2 is a central regulator of both strigolactone and KAR signaling pathways, which control many aspects of plant growth and development. KARs binding may produce conformational variations in $\alpha / \beta$-fold hydrolase KAI2 and its link with MAX2, an F-box constituent of E3 ubiquitin-protein ligase, and in this manner, targeting the signaling repressor(s) for degradation [144]. MAX2 in turn affects the SMAX1- and SMAX1-like proteins downstream and could be the hypothetical repressors. Strigolactone and karrikins commonly involved in seed development, growth of axillary meristems, and senescence of leaves [145]. The similar F-box protein (MAX2) and $\alpha / \beta$ hydrolase fold proteins (DAD2 and KAI2) are required for the signal transduction pathways. Structure activity relationships of analogs have indicated that both strigolactones and karrikins consist of butenolide ring that is important for biological reaction, but the rest of the molecules can be considerably modified without loss of activity. The relationship examination of strigolactones and karrikins proposed their reception by an active enzyme which then reacts with the SCF complex and presumably degrades downstream target proteins [145].

Clear evidenc about the common signal transduction mechanism of strigolactone and karrikins was found in Arabidopsis $[96,146]$. In Arabidopsis for karrikins responses, two genes, MAX2 and KAI2, are essential. KAI2 encodes $\alpha / \beta$-hydrolase fold protein with an analogous structure to AtD14; therefore, it is also known as AtD14-like. The binding assay and phenotype study proposed $t$ KAI2 as putative receptor of karrikins; thus, AtD14 and KAI2 especially facilitate plant growth to strigolactones and karrikins, respectively. Analogous phenomena were involved in strigolactone signaling, a protein, 
termed as SMAX1. Studies reveal that this protein is responsible for suppressing karrikin signaling in Arabidopsis [147]. It is suggested that SMAX1, as a specific repressor of karrikin signaling, contrary to D53, was reported to play a role in seed germination and hypocotyl elongation through KAI2-MAX2 signaling, but not in shoot branching that is controlled by AtD14-MAX2 signaling activated by strigolactones. Extending the previous investigations, it was further explained that SMXL2 controls hypocotyl growth and expression of the KAR/strigolactone transcriptional markers SMAX1 along with KUF1, IAA1, and DLK2 redundantly [148]. Hypocotyl growth in the double mutant smax1 smxl2 is insensitive to KAR and strigolactone, resulting in reduced hypocotyl elongation. These results support the model that karrikin and strigolactone responses are mediated by different subclades of the SMXL family, and further support the case for similar butenolide signaling pathways that evolved through ancient KAI2 and SMXL duplications [148]. Summarizing all evidence, it was pointed out that despite massive explanations, there is still a huge need for further investigations of this classic family [149].

In order to explain how KAI 2 operates, various kai2 mutations were evaluated. Among those, most were unable to accumulate the protein, which, therefore, was supposed to be unstable compared to wild type. Only one mutant (kai2-10) formed a protein with similar stability to the wild type, although a non-functional one. The abundance of KAI2 protein in kai2-10 compared with the wild type was different across various experiments, which was not explained further [150]. Their results demonstrated that the enzymatic and signaling functions of KAI2 can be decoupled and provide important insights into the mechanistic events that support butenoloides signaling in plants.

Two other structurally-related compounds, (5RS)-3,4,5-trimethylfuran-2(5H)-one and 5,5-dimethylfuran-2(5H)-one, were also isolated from plant-derived smoke with an antagonistic effect against KAR1 and an inhibitory effect on seed germination of light-sensitive lettuce [24]. This investigation pointed out the dual regulatory mechanism of plant-derived smoke on post-fire seedling emergence. This leads to smoke being interpreted as a wise regulator that prevents germination when the moisture is insufficient to support the newly emerged seedling growth. However, after rainfall, this restraint is overcome by diluting the inhibitory compound in smoke which is leached out while promoting compounds are retained. Although, this supposition is quite convincing, great technology-equipped research is required to analyze and validate it widely.

\subsection{Effect on Proteins in Plants of Plant-Derived Smoke}

A proteomic approach was used to identify early karrikin-response proteins, and most of karrikin-response specific proteins were photosynthesis-, carbohydrate metabolism-, redox homeostasis-, transcription control-, transport-, and protein degradation-related proteins in Arabidopsis seedlings [136]. However, because there are many questions on whether karrikins are main compounds, the usage of plant-derived smoke solution is important (Figure 3).

Using the gel-free/label-free proteomic technique, proteins related to signaling and transport increased; however, protein metabolism-, cell-, and cell wall-related proteins decreased in chickpea [73]. The sucrose synthase for starch degradation and proteins for the nitrate pathway increased resulting in an increase in total soluble sugars and nitrate contents, respectively. This increase in plant growth-related proteins is a reinforcement of the fact that plant-derived smoke improves the early stage of growth in chickpea with the balance of many cascades such as glycolysis, redox homeostasis, and secondary metabolism. Additionally, proteins related to sucrose synthase, nucleotides, signaling, and glutathione significantly increased; however, cell wall-, lipid-, photosynthetic-, and amino acid degradation-related proteins decreased in maize [74]. These results suggested that increases in sucrose synthase-, nucleotide-, signaling-, and glutathione-related proteins combined with regulation of reactive oxygen species and their scavenging system in response to plant-derived smoke may improve maize growth. 


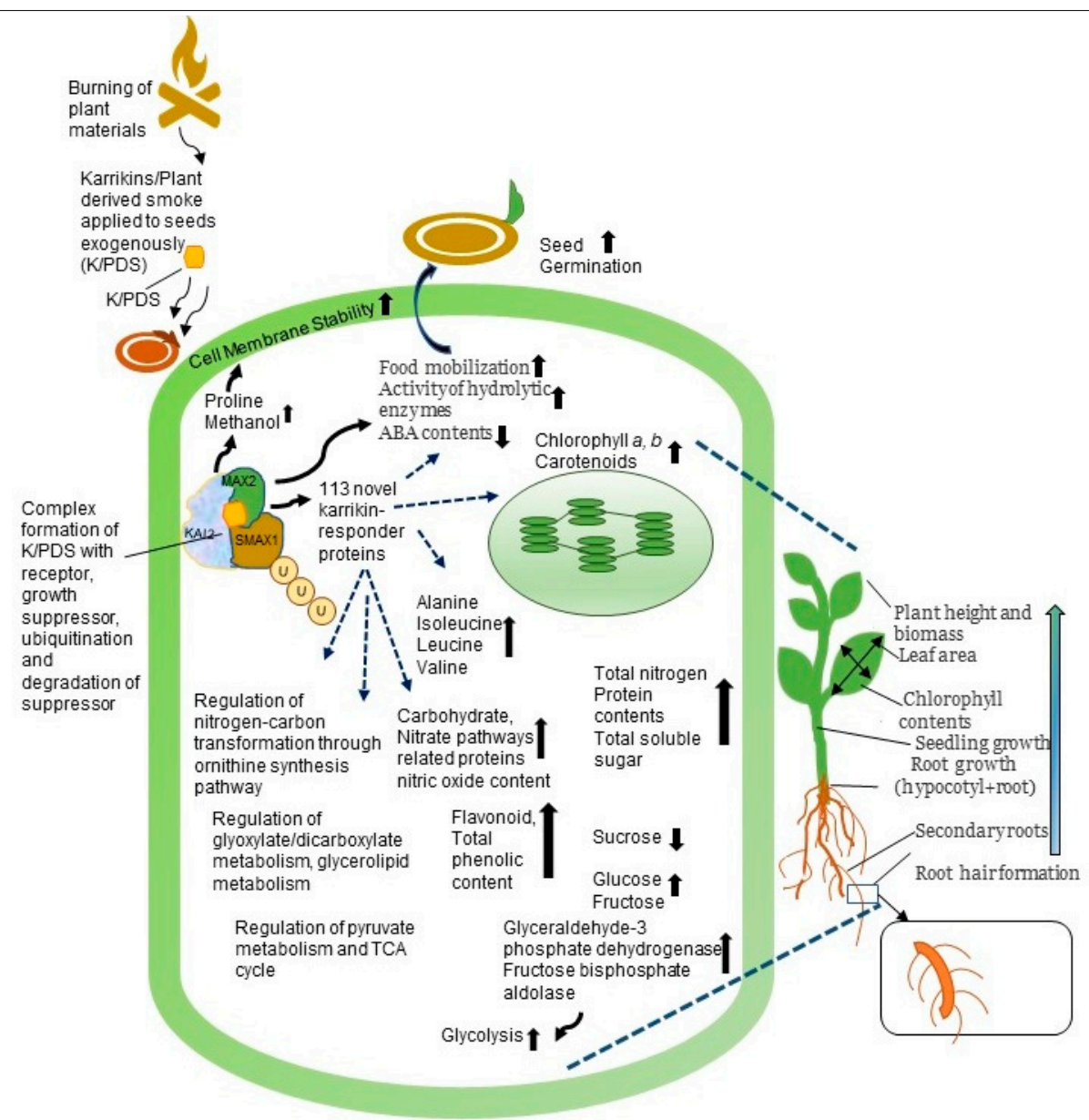

Figure 3. Schematic diagram showing diverse cellular responses to plant-derived smoke. Plant-derived smoke triggers regulation of various metabolic processes resulting in acceleration of seed germination and other growth processes. Upward and downward arrows indicate increased and decreased metabolic processes in response to plant-derived smoke, respectively. The dashed lines represent the possible relationship between smoke induced changes at molecular level and their effects. Abbreviations are as follows: K/PDS, karrikins/plant-derived smoke; KAI2, $\alpha / \beta$ hydrolases receptors of karrikins; MAX2, F-box subunit of a SCF class of E3 ubiquitin-protein ligase complex; SMAX1, a growth suppressor protein; and TCA, carboxylic acid cycle.

A proteomic analysis was applied on soybean seedlings recovering from flooding stress followed by treatment with plant-derived smoke solution. It was investigated that sucrose/starch metabolismand glycolysis-related proteins were suppressed in smoke-treated flooded soybean compared to flooded soybean [14]. A supportive effect of plant-derived smoke solution on soybean growth was thus established during recovery from flooding stress by balancing sucrose/starch metabolismand glycolysis-related proteins. Furthermore, plant-derived smoke solution might enhance plant growth through the ornithine-synthesis and ubiquitin-proteasome pathway in soybean seedlings [138]. This result indicated that plant-derived smoke induced a sacrifice-for-survival mechanism in soybean seedlings during recovery after flooding causing the inhibition of the ubiquitin-proteasome pathway leading to degradation of the root tip and promotion of the lateral root development. A positive trend of smoke-treated soybean seedlings was identified in stress tolerance against flooding. This tolerance involved an abundance of ATPase, ATP content, and activation of ascorbate/glutathione cycle in response to plant-derived smoke under flooding stress [139]. These reports concluded that plant-derived smoke promoted soybean normal growth by the regulation of nitrogen-carbon transformation through the ornithine synthesis pathway and ubiquitin-proteasome pathway (Table 4). 
The impact of KAR1 on tanshinone-I production and involved signal molecules was reported in red sage [140]. It was clarified that KAR1 induced generation of nitric oxide, jasmonic acid, and tanshinone-I in hairy roots of red sage. The KAR1-induced increase in tanshinone-I was suppressed by nitrogen oxide-specific scavenger (cPTIO) and nitrogen oxide inhibitors (PBITU); jasmonic acid synthesis inhibitors (SHAM) and (PrGall). These results provided the evidence that nitrogen oxide and jasmonic acid have essential roles in KAR1-induced tanshinone-I aside from other assumptions, and it can be inferred that nitrogen oxide mediated the KAR1-induced tanshinone-I production through a jasmonic acid-dependent signaling pathway which ultimately resulted in hairy roots of red sage. Modifications in gene expression, proteomic responses, and changes in tanshinone-I production and involved signal molecules in smoke-treated plants under both favorable and unfavorable conditions enrich the evidence leading to the use of plant-derived smoke as a biostimulant. A significant tolerance to abiotic stresses was reported [151] explaining that karrikin-KAI2 signaling provides arabidopsis seeds with tolerance to abiotic stress and inhibits germination under conditions unfavorable to seedling establishment. This wise regulation activity induced by plant-derived smoke changes smoke/karrikins from being a positive regulator of germination to an inhibitor resulting from the transcription of genes encoding stress response transcription factors such as WRKY33, ERF5, and DREB $2 A$ in a KAI2-dependent manner. However, the mechanistic details behind this mysterious reversal are yet to be understood [151]. Taken together, the results infer that smoke treatment enables plants to adopt various strategies under unfavorable conditions for protection against abiotic stresses. These strategies may involve suppression/halting the growth or promoting the growth-related activities to successfully endure the stress period $[139,151,152]$. This is evident from the aforementioned facts that exogenous application of plant-derived smoke ameliorates flooding-induced damages in soybean. This potential of plant-derived smoke treatment for extenuation of the flooding stress effect on plants shows its worth for stress amelioration.

\section{Conclusions}

Plant-derived smoke solution has established an incredible role in breaking seed dormancy, accelerating seed germination, and increasing seedling vigor. Previous studies resulted in the identification of numerous novel karrikins, smoke-responsive genes, and proteins that provide novel targets for detailed mechanistic studies using mutants and transgenic plants. Plant-derived smoke has conferred tolerance to plants against abiotic stresses that is attributed to its role in the regulation of the antioxidant system of plants. The role of plant-derived smoke in growth regulation under normal conditions and abiotic stresses has authenticated its candidature as the most economic and convenient biostimulant for farmers. Despite improvement in understanding the response mechanisms of plants regarding plant-derived smoke, more in-depth interdisciplinary research with a combination of omics, inter-system combinations of various scientific expertise, and interconnecting biological approaches is needed to resolve the whole chemistry and perception/signaling pathways of karrikins/plant-derived smoke. Especially interrelating omics technologies are to be performed to trace the independent response mechanism of plants irrespective of the presence of other growth regulators. A further task will be to clarify the extent of KAI2-related phenomena and how they facilitate various growth processes. The fact that whether karrikins themselves are metabolized or just triggering a series of reactions resulting in growth regulation is yet to be unraveled. Furthermore, independent separation of promoting and inhibitory compounds is required for the explanation of their specific correlation with growth phenomena that we aimed for. Based on this information, plant-derived smoke applications should also be performed in the laboratory and field before accepting them at a wide agricultural level to optimize their benefits.

Supplementary Materials: Supplementary materials can be found at http://www.mdpi.com/1422-0067/21/20/7760/s1. Author Contributions: Conceptualization, S.K. and A.K.; writing, A.K. and S.K.; review and editing, S.K.; reading, S.U.R., M.M.A. and M.J. All authors have read and agreed to the published version of the manuscript. 
Funding: This research received no external funding.

Conflicts of Interest: The authors declare no conflict of interest.

\section{Abbreviation}

KAR Karrikins

\section{References}

1. De Lange, J.H.; Boucher, C. Auto ecological studies on Audinia capitata (Bruniaceaae), plant-derived smoke as a germination cue. S. Afr. J. Bot. 1990, 56, 188-202. [CrossRef]

2. Brown, N.A.C. Promotion of germination of fynboss seeds by plant-derived smoke. New Phytol. 1993 . 123, 575-583. [CrossRef]

3. Van Staden, J.; Sparg, S.G.; Kulkarni, M.G.; Light, M.E. Post-germination effects of the smoke-derived compound 3-methyl-2H-furo[2,3-c] pyran-2-one, and its potential as a preconditioning agent. Field Crops Res. 2006, 98, 98-105. [CrossRef]

4. Paul, B.T.; Charles, E.M.; Tony, D.A. Response surfaces for the combined effects of heat shock and smoke on germination of 16 species forming soil seed bank in South- East Australia. Austral Ecol. 2007, 32, 605-616.

5. Mandal, K.; Misra, A.; Hati, K.; Bandyopadhyay, K.; Ghosh, P.; Mohanty, M. Rice residue-management options and effects on soil properties and crop productivity. J. Food Agric. Environ. 2004, 2, 224-231.

6. Todorovic, S.; Giba, Z.; Zivkovic, S.; Grubisic, D.; Konjevic, R. Stimulation of empress tree seed germination by liquid smoke. Plant Growth Regul. 2005, 47, 141-148. [CrossRef]

7. Light, M.E.; Gardner, M.J.; Jager, A.K.; van Staden, J. Dual regulation of seed germination by smoke solution. Plant Growth Regul. 2002, 37, 135-141. [CrossRef]

8. Brown, N.A.C.; van Staden, J.; Daws, M.I.; Johnson, T. Patterns in the seed germination response to smoke in plants from the Cape Floristic Region, South Africa. S. Afr. J. Bot. 2003, 69, 514-525. [CrossRef]

9. Egerton-Warburton, L. A smoke-induced alteration of the sub-testa cuticle in seeds of the post-fire recruiter, Emmenanthe penduliflora Benth. (Hydrophyllaceae). J. Exp. Bot. 1998, 49, 1317-1327. [CrossRef]

10. Keely, J.E.; Fotheringham, C.J. Smoke-induced seed germination in Californian chaparral. Ecology 1998, 79, 2320-2336. [CrossRef]

11. Flematti, G.R.; Ghisalberti, E.L.; Dixon, K.W.; Trengove, R.D. A compound from smoke that promotes seed germination. Science 2004, 305, 977. [CrossRef]

12. Aslam, M.M.; Jamil, M.; Khatoon, A.; Hendawy, S.E.; AL-Suhaibani, N.A.; Malook, I.; Rehman, S.U. Physiological and biochemical responses of maize (Zea mays L.) to plant derived smoke solution. Pak. J. Bot. 2017, 49, 435-443.

13. Jamil, M.; Kanwal, M.; Aslam, M.M.; Khan, S.S.; Malook, I.; Tu, J.; Rehman, S.U. Effect of plant-derived smoke priming on physiological and biochemical characteristics of rice under salt stress condition. Aust. J. Crop. Sci. 2014, 8, 159-170.

14. Li, X.; Rehman, S.U.; Yamaguchi, H.; Hitachi, K.; Tsuchida, K.; Yamaguchi, T.; Sunohara, Y.; Matsumoto, H.; Komatsu, S. Proteomic analysis of the effect of plant-derived smoke on soybean during recovery from flooding stress. J. Proteomic. 2018, 181, 238-248. [CrossRef] [PubMed]

15. Akhtar, N.; Khan, S.; Malook, I.; Rehman, S.U.; Jamil, M. Pb-induced changes in roots of two cultivated rice cultivars grown in lead-contaminated soil mediated by smoke. Environ. Sci. Pollut. Res. 2017, 24, 21298-21310. [CrossRef]

16. Brown, N.A.C.; van Staden, J. Smoke as a germination cue: A review. Plant Growth Regul. 1997, 22, 115-124. [CrossRef]

17. Jager, A.K.; Light, M.E.; van Staden, J. Effects of source of plant material and temperature on the production of smoke extracts that promote germination of light-sensitive lettuce seeds. Environ. Exp. Bot. 1996, 36, 421-429. [CrossRef]

18. Nelson, D.C.; Flematti, G.R.; Ghisalberti, E.L.; Dixon, K.W.; Smith, S.M. Regulation of seed germination and seedling growth by chemical signals from burning vegetation. Ann. Rev. Plant Biol. 2012, 63, 107-130. [CrossRef] 
19. Adriansz, T.D.; Rummey, J.M.; Bennett, I.J. Solid phase extraction and subsequent identification by gas chromatography, Mass-Spectrometry of a germination cue present in smoky water. Anal. Lett. 2000, 33, 2793-2804. [CrossRef]

20. Light, M.E.; Burger, B.V.; Staerk, D.; Kohout, L.; van Staden, J. Butenolides from plant-derived smoke: Natural plant growth regulators with antagonistic actions on seed germination. J. Nat. Prod. 2010, 73, 267-269. [CrossRef] [PubMed]

21. Flematti, G.R.; Merritt, D.J.; Piggott, M.J.; Trengove, R.D.; Smith, S.M.; Dixon, K.W.; Ghisalberti, E.L. Burning vegetation produces cyanohydrins that liberate cyanide and promote seed germination. Nat. Commun. 2011, 2, 360. [CrossRef]

22. Wang, M.; Schoettner, M.; Xu, S.; Paetz, C.; Wilde, J.; Baldwin, I.T.; Groten, K. Catechol, a major component of smoke, influences primary root growth and root hair elongation through reactive oxygen species-mediated redox signaling. New Phytologist. 2017, 213, 1755-1770. [CrossRef] [PubMed]

23. Kamran, M.; Khan, A.L.; Ali, L.; Hussain, J.; Waqas, M.; Al-Harrasi, A.; Lee, I.J. Hydroquinone; a novel bioactive compound from plant-derived smoke can cue seed germination of lettuce. Front. Chem. 2017, 5, 30. [CrossRef]

24. Burger, B.V.; Postac, M.; Lightb, M.E.; Kulkarni, M.G.; Viviersa, M.Z.; van Staden, J. More butenolides from plant-derived smoke with germination inhibitory activity against karrikinolide. S. Afr. J. Bot. 2018, 115, 256-263. [CrossRef]

25. Flematti, G.R.; Ghisalberti, E.L.; Dixon, K.W.; Trengove, R.D. Synthesis of the seed germination stimulant 3-methyl-2H-furo[2,3-c] pyran-2-one. Tetrahedron Lett. 2005, 46, 5719-5721. [CrossRef]

26. Brown, N.A.C.; Botha, P.A. Smoke seed germination studies and a guide to seed propagation of plants from major families of the Cape floristic region, South Africa. S. Afr. J. Bot. 2004, 70, 559-581. [CrossRef]

27. Flematti, G.R.; Goddard-Berg, E.D.; Merritt, D.J.; Ghisalberti, E.L.; Dixon, K.W.; Trengove, R.D. Preparation of 3-methyl-2H-furo[2,3-c] pyran-2-one derivatives and evaluation of their germination-promoting activity. J. Agric. Food Chem. 2007, 55, 2189-2194. [CrossRef]

28. Flematti, G.R.; Ghisalberti, E.L.; Dixon, K.W.; Trengove, R.D.; Skelton, B.W.; White, A.H. Structural analysis of a potent seed germination stimulant. Aust. J. Chem. 2005, 58, 505-506. [CrossRef]

29. Flematti, G.R.; Scaffidi, A.; Goddard-Borger, E.D.; Heath, C.H.; Nelson, D.C.; Commander, L.E.; Stick, O.V.R.; Dixon, W.; Smith SMGhisalberti, E.L. Structure-activity relationship of karrikin germination stimulants. J. Agric. Food Chem. 2010, 58, 8612-8617. [CrossRef]

30. Goddard-Borger, E.D.; Ghisalberti, E.L.; Stick, R.V. Synthesis of the germination stimulant 3-methyle-2H-furo[2,3-c] pyran-2-one and analogous compounds from carbohydrates. Eur. J. Org. Chem. 2007, 2007, 3925-3934. [CrossRef]

31. Dixon, K.W.; Merritt, D.J.; Flematti, G.R.; Ghisalberti, E.L. Karrikinolide-a phytoreactive compound derived from smoke with applications in horticulture, ecological restoration and agriculture. Acta Hortic. 2009, 813, 155-170. [CrossRef]

32. Merritt, D.J.; Turner, S.R.; Clark, S.; Dixon, K.W. Seed dormancy and germination stimulation syndromes for Australian temperate species. Aust. J. Bot. 2007, 55, 336-344. [CrossRef]

33. Iqbal, M.; Asif, S.; Ilyas, N.; Raja, N.I.; Hussain, M.; Sabir, S.; Faz, M.N.A.; Rauf, A. Effect of plant derived smoke on germination and post germination expression of wheat (Triticum aestivum L.). Am. J. Plant Sci. 2016, 7, 806-813. [CrossRef]

34. Kulkurni, M.G.; Ascough, G.D.; van Staden, J. Smoke-water and smoke-isolated butenolide improve growth and yield of tomatoes under greenhouse conditions. Hortic. Technol. 2008, 18, 449-454. [CrossRef]

35. Elsadek, M.A.; Yousef, E.A.A. Smoke-water enhances germination and seedling growth of four horticultural crops. Plants 2019, 8, 104. [CrossRef]

36. Aremu, A.O.; Kulkarni, M.G.; Bair, M.O.; Finnie, J.F.; van Staden, J. Growth stimulation effects of smoke-water and vermin-compost leachate on greenhouse grown-tissue cultured 'Williams' bananas. Plant Growth Regul. 2012, 66, 111-118. [CrossRef]

37. Verschaeve, L.; Maes, J.; Light, M.E.; van Staden, J. Genetic toxicity testing of 3-methyl-2H-furo[2,3-c] pyran-2-one, an important biological active compound from plant-derived smoke. Mutat. Res. Gen. Toxicol. Environ. Mutagen. 2006, 611, 89-95. [CrossRef] 
38. Jain, N.; Kulkarni, M.G.; van Staden, J. A butenolide isolated from smoke, can overcome the detrimental effects of extreme temperature during tomato seed germination. Plant Growth Regul. 2006, 49, 263-267. [CrossRef]

39. Waheed, M.A.; Jamil, M.; Khan, M.D.; Shakir, S.K.; Rehman, S.U. Effect of plant-derived smoke solutions on physiological and biochemical attributes of maize (Zea mays L.) under salt stress. Pak. J. Bot. 2016 $48,1763-1774$.

40. Malook, I.; Itlas, A.; Rehman, S.U.; Weng, W.; Jamil, M. Smoke alleviates adverse effects induced by stress on rice. Toxicol. Environ. Chem. 2014, 96, 755-767. [CrossRef]

41. Oracz, K.; El-Maarouf-Bouteau, H.; Kranner, I.; Bogatek, R.; Corbineau, F.; Bailly, C. The mechanisms involved in seed dormancy alleviation by hydrogen cyanide unravel the role of reactive oxygen species as key factors of cellular signaling during germination. Plant Physiol. 2009, 150, 494-505. [CrossRef]

42. Van Staden, J.; Jager, A.K.; Light, M.E.; Burger, B.V. Isolation of the major germination cue from plant-derived smoke. S. Afr. J. Bot. 2004, 70, 654-659. [CrossRef]

43. Yakhin, O.I.; Lubyanov, A.A.; Yakhin, I.A.; Brown, P.H. Biostimulants in plant science: A global perspective Front. Plant Sci. 2017, 7, 2049. [CrossRef] [PubMed]

44. Ngoroyemoto, N.; Gupta, S.; Kulkarni, M.G.; Finnie, J.F.; Van Staden, J. Effect of organic biostimulants on the growth and biochemical composition of Amaranthus hybridus L. S. Afr. J. Bot. 2019, 124, 87-93. [CrossRef]

45. Nemahunguni, N.K.; Gupta, S.; Kulkarni, M.G.; Finnie, J.F.; Van Staden, J. The effect of biostimulants and light wavelengths on the physiology of Cleome gynandra seeds. Plant Growth Regul. 2019, 90, 467-474. [CrossRef]

46. Kamran, M.; Imran, Q.M.; Khatoon, A.; Lee, I.J.; Rehman, S.U. Effect of plant extracted smoke and reversion of abscisic acid stress on lettuce. Pak. J. Bot. 2013, 45, 1541-1549.

47. Raizada, P.; Raghubanshi, A.S. Seed germination behavior of Lantana camara in response to smoke. Trop. Ecol. 2010, 51, 347-352.

48. Zhou, J.; van Staden, J.; Guo, L.P.; Huang, L.Q. Smoke-water improves shoot growth and indigo accumulation in shoots of Isatis indigotica seedlings. S. Afr. J. Bot. 2011, 77, 787-789. [CrossRef]

49. Tavsanoglu, C. Fire-related cues (heat shock and smoke) and seed germination in a Cistus creticus population in south western Turkey. Ekoloji 2011, 20, 99-104.

50. Schwilk, D.W.; Zavala, N. Germination response of grassland species to plant-derived smoke. J. Arid Environ. 2012, 79, 111-115. [CrossRef]

51. Chumpookam, J.; Lin, H.L.; Shiesh, C.C.; Ku, K.L. Effect of smoke-water on seed germination and resistance to Rhizoctonia solani inciting papaya damping-off. Hortic. Sci. 2012, 37, 13-29.

52. Ghazanfaria, P.; Abdollahia, M.R.; Moienib, A.; Moosavia, S.S. Effect of plant-derived smoke extract on in vitro plantlet regeneration from rapeseed (Brassica napus L. cv. Topas) microspore-derived embryos. Int. J. Plant Prod. 2012, 6, 309-324.

53. Tormo, J.; Moreira, B.; Pausas, J.G. Field evidence of smoke-stimulated seedling emergence and establishment in Mediterranean Basin flora. J. Veg. Sci. 2013, 25, 771-777. [CrossRef]

54. Aremu, A.O.; Masondo, N.A.; van Staden, J. Smoke-water stimulates secondary metabolites during in vitro seedling development in Tulbaghia species. S. Afr. J. Bot. 2014, 91, 49-52. [CrossRef]

55. Catav, S.S.; Kucukakyuz, K.; Akbas, K.; Tavsanoglu, C. Smoke-enhanced seed germination in Mediterranean Lamiaceae. Seed Sci. Res. 2014, 24, 257. [CrossRef]

56. Preston, C.A.; Becker, R.; Baldwin, I.T. Is 'NO' news good news? Nitrogen oxides are not components of smoke that elicits germination in two smoke-stimulated species, Nicotiana attenuate and Emmenanthe penduliflora. Seed Sci. Res. 2014, 14, 73-79. [CrossRef]

57. Aslam, M.M.; Akhter, A.; Jamil, M.; Khatoon, A.; Malook, I.; Rehman, S.U. Effect of Plant-derived smoke solution on root of Ipomoea marguerite cuttings under cobalt stress. J. Bio Mol. Sci. 2014, 2, 6-11.

58. Pirzada, K.; Shafiq, U.R.; Jamil, M.; Irfan, S.; Waheed, M.A.; Aslam, M.M.; Kanwal, M.; Shakir, S.K. Alleviation of boron stress through plant derived smoke extracts in Sorghum bicolor. J. Stress Physiol. Biochem. 2014, 10, 153-165.

59. Asaf, S.; Imran, Q.M.; Khatoon, A.; Lubna, J.R.; Jung, H.-Y.; Rehman, S.U. Plant derived smoke promotes seed germination and alleviates auxin stress in carrot. J. Agric. Biol. Sci. 2014, 9, 308-314.

60. Kamran, M.; Khan, A.L.; Waqas, M.; Imran, Q.M.; Hamayun, M.; Kang, S.M.; Kim, Y.H.; Kim, M.J.; Lee, I.J Effects of plant-derived smoke on the growth dynamics of Barnyard Grass (Echinochloa crus-galli). Acta Agric. Scand. Sect. B Soil Plant Sci. 2014, 64, 121-128. [CrossRef] 
61. Abu, Y.; Romo, J.T.; Bai, Y.; Coulman, B. Priming seeds in aqueous smoke solutions to improve seed germination and biomass production of perennial forage species. Can. J. Plant Sci. 2016, 96, 551-563. [CrossRef]

62. Catav, S.S.; Kuçukakyuz, K.; Tavsanoglu, C.; Akbas, K. Effects of aqueous smoke and nitrate treatments on germination of 12 eastern mediterranean basin plants. Ann. Bot. Fenn. 2015, 52, 93-100. [CrossRef]

63. Fornwalt, P.J. Does smoke promote seed germination in 10 Interior West Penstemon species? Nat. Plants J. 2015, 16, 5-12. [CrossRef]

64. Ren, L.; Bai, Y. Smoke originated from different plants has various effects on germination and seedling growth of species in Fescue Prairie. Botany 2016, 94, 1141-1150. [CrossRef]

65. Martinez-Baniela, M.; Carlon, L.; Diaz, T.E.; Bueno, A.; Fernandez-Pascual, E. Plant-derived smoke and temperature effects on seed germination of five Helianthemum (Cistaceae). Flora 2016, 223, 56-61. [CrossRef]

66. Naghipour, A.A.; Bashari, H.; Khajeddin, S.J.; Tahmasebi, P.; Iravani, M. Effects of smoke, ash and heat shock on seed germination of seven species from Central Zagros rangelands in the semi-arid region of Iran. Afr. J. Range Forage Sci. 2016, 33, 67-71. [CrossRef]

67. Mukundamago, M.; Adu-Acheampong, S.; Moshobane, M.C. Impact of gaseous smoke treatment on germination and seedling emergence of the cape flats sand fynbos species. Asian J. Plant Sci. Res. 2017, 7, 50-59.

68. Cembrowska-Lech, D.; Kępczyńsk, J. Plant-derived smoke induced activity of amylases, DNA replication and $\beta$-tubulin accumulation before radicle protrusion of dormant Avena fatua L. caryopses. Acta Physiol. Plant. 2017, 39, 39-50. [CrossRef]

69. Cox, R.D.; Chou, Y.F.; Wester, D.B. Smoke water and heat influence emergence of shortgrass prairie species. Fire Ecol. 2017, 13, 138-148. [CrossRef]

70. Catav, S..S.; Kucukakyuz, K.; Tavşanoglu, C.; Pausas, J.G. Effect of fire-derived chemicals on germination and seedling growth in Mediterranean plant species. Basic Appl. Ecol. 2018, 30, 65-75. [CrossRef]

71. Moreira, B.; Pausas, J.G. Shedding light through the smoke on the germination of Mediterranean Basin flora S. Afr. J. Bot. 2018, 115, 244-250. [CrossRef]

72. Plazek, A.; Dubert, F.; Kopec, P.; Dziurka, M.; Kalandyk, A.; Pastuszak, J.; Wolko, B. Seed hydropriming and smoke water significantly improve low-temperature germination of Lupinus angustifolius L. Int. J. Mol. Sci. 2018, 19, 992. [CrossRef] [PubMed]

73. Rehman, A.; Rehman, S.U.; Khatoon, A.; Qasim, M.; Itohd, T.; Iwasakid, Y.; Wang, X.; Sunohara, Y. Matsumoto, H.; Komatsu, S. Proteomic analysis of the promotive effect of plant-derived smoke on plant growth of chickpea. J. Proteom. 2018, 176, 56-70. [CrossRef] [PubMed]

74. Aslam, M.M.; Rehman, S.U.; Khatoon, A.; Jamil, M.; Yamaguchi, H.; Hitachi, K.; Tsuchida, K.; Sunohara, Y.; Matsumoto, H.; Komatsu, S. Proteomic analysis of the effect of plant-derived smoke on maize growth. Int. J. Mol. Sci. 2019, 20, 1319. [CrossRef] [PubMed]

75. Gupta, S.; Hrdlička, J.; Ngoroyemoto, N.; Nemahunguni, N.K.; Gucký, T.; Novák, O.; Kulkarni, M.J.; Dolezal, K.; van Staden, J. Preparation and standardisation of smoke-water for seed germination and plant growth stimulation. Plant Growth Regul. 2019, 39, 338-345. [CrossRef]

76. Roeder, M.; Yang, W.; Tomlinson, K.W. Influence of smoke, heat and fire on germination of woody species occurring in the dry valleys of southwest China. J. Plant Ecol. 2019, 12, 931-940. [CrossRef]

77. Jamil, M.; Jahangir, M.; Rehman, S.U. Smoke induced physiological, biochemical and molecular changes in germinating rice seeds. Pak. J. Bot. 2020, 52, 865-871. [CrossRef]

78. Posta, M.; Light, M.E.; Papenfus, H.B.; van Staden, J.; Kohout, L. Structure-activity relationships of analogs of 3,4,5- trimethylfuran-2(5H)-one with germination inhibitory activities. J. Plant Physiol. 2013, 170, 1235-1242. [CrossRef]

79. Ghebrehiwot, H.M.; Kulkarni, M.G.; Szalai, G.; Soos, V.; Balazs, E.; van Staden, J. Karrikinolide residues in grassland soils following fire: Implications on germination activity. S. Afr. J. Bot. 2013, 88, 419-424. [CrossRef]

80. Baldos, O.C.; DeFrank, J.; Sakamoto, G.S. Germination response of dormant tanglehead (Heteropogon contortus) seeds to smoke-infused water and the smoke-associated stimulatory compounds, karrikinolide and cyanide. HortScience 2015, 50, 421-429. [CrossRef] 
81. Gupta, S.; Plackova, L.; Kulkarni, M.G.; Dolezal, K.; van Staden, J. Role of Smoke Stimulatory and Inhibitory Biomolecules in Phytochrome-Regulated Seed Germination of Lactuca sativa. Plant Physiol. 2019, 181, 458-470. [CrossRef]

82. Mavi, K.; Light, M.E.; Demir, I.; van Staden, J.; Yasar, F. Positive effect of smoke-derived butenolide priming on melon seedling emergence and growth. N. Z. J. Crop. Hort. 2010, 38, 147-155. [CrossRef]

83. Downes, K.S.; Lamont, B.B.; Light, M.E.; van Staden, J. The fire ephemeral Tersonia cyathiflora (Gyrostemonaceae) germinates in response to smoke but not the butenolide 3-methyl-2H-furo [2,3-c]pyran-2-one. Ann Bot. 2010, 106, 381-384. [CrossRef]

84. Long, R.L.; Williams, K.; Griffiths, E.M.; Flematti, G.R.; Merritt, D.J.; Stevens, J.C.; Turner, S.R.; Powles, S.B.; Dixon, K.W. Prior hydration of Brassica tournefortii seeds reduces the stimulatory effect of karrikinolide on germination and increases seed sensitivity to abscisic acid. Ann. Bot. 2010, 105, 1063-1070. [CrossRef] [PubMed]

85. Kandari, L.S.; Kulkarni, M.G.; van Staden, J. Effect of nutrients and smoke solutions on seed germination and seedling growth of tropical soda apple (Solanum viarum). Weed Sci. 2011, 59, 470-475. [CrossRef]

86. Long, R.L.; Stevens, J.C.; Griffiths, E.M.; Adamek, M.; Powles, S.B.; Merritt, D.J. Detecting karrikinolide responses in seeds of the Poaceae. Aust. J. Bot. 2011, 59, 609-619. [CrossRef]

87. Aremu, A.O.; Bairu, M.W.; Finnie, J.F.; van Staden, J. Stimulatory role of smoke-water and karrikinolide on the photosynthetic pigment and phenolic contents of micro-propagated 'Williams' bananas. Plant Growth Regul. 2012, 67, 271-279. [CrossRef]

88. Kulkarni, M.G.; Amoo, S.O.; Kandari, L.S.; van Staden, J. Seed germination and phytochemical evaluation in seedlings of Aloe arborescens Mill. Plant Biosyst. 2013, 148, 460-466. [CrossRef]

89. Kumari, A.; Papenfus, H.B.; Kulkarni, M.G.; Posta, M.; van Staden, J. Effect of smoke derivatives on in vitro pollen germination and pollen tube elongation of species from different plant families. Plant Biol. 2015, 17, 825-830. [CrossRef] [PubMed]

90. Okem, A.; Kulkarni, M.G.; van Staden, J. Enhancing Phytoremediation Potential of Pennisetum clandestinum Hochst in cadmium contaminated soil using smoke-water and smoke isolated karrikinolide Int. J. Phytoremediat. 2015, 17, 1046-1052. [CrossRef]

91. Papenfus, H.B.; Kulkarni, M.G.; Stirk, W.A.; Rengasamy, K.R.R.; Salomon, M.V.; Piccoli, P.; Bottini, R. van Staden, J. Interactions between a plant growth-promoting rhizobia bacterium and smoke-derived compounds and their effect on okra growth. J. Plant Nutr. Soil Sci. 2015, 178, 741-747. [CrossRef]

92. Ren, L.; Bai, Y.; Reaney, M. Evidence of different compounds in smoke derived from legumes and grasses acting on seed germination and seedling emergence. Seed Sci. Res. 2017, 27, 154-164. [CrossRef]

93. Downes, K.S.; Light, M.E.; Posta, M.; Kohout, L.; van Staden, J. Comparison of germination responses of Anigozanthos flavidus (Haemodoraceae), Gyrostemon racemiger and Gyrostemon ramulosus (Gyrostemonaceae) to smoke-water and the smoke-derived compounds karrikinolide (KAR1) and glyceronitrile. Ann Bot. 2013. 111, 489-497. [CrossRef] [PubMed]

94. Ma, H.; Erickson, T.E.; Merritt, D.J. Seed dormancy regulates germination response to smoke and temperature in a rhizomatous evergreen perennial. AoB Plants 2018, 10, 42. [CrossRef]

95. Nelson, D.C.; Flematti, G.R.; Riseborough, J.A.; Ghisalberti, E.L.; Dixon, K.W.; Smith, S.M. Karrikins enhance light responses during germination and seedling development in Arabidopsis thaliana. Proc. Natl. Acad. Sci. USA 2010, 107, 7095-7100. [CrossRef]

96. Nelson, D.C.; Scaffidi, A.; Dun, E.A.; Waters, M.T.; Flematti, G.R.; Dixon, K.W.; Beveridge, C.A.; Ghisalberti, E.L.; Smith, S.M. F-box protein MAX2 has dual roles in karrikin and strigolactone signaling in Arabidopsis thaliana. Proc. Natl. Acad. Sci. USA 2011, 108, 8897-8902. [CrossRef] [PubMed]

97. Khan, M.H.U.; Khattak, J.Z.K.; Jamil, M.; Malook, I.; Khan, S.U.; Jan, M.; Din, I.; Saud, S.; Kamran, M.; Alharby, H.; et al. Bacillus safensis with plant-derived smoke stimulates rice growth under saline conditions. Environ. Sci. Pollut. Res. 2017, 24, 23850-23863. [CrossRef]

98. van Staden, J.; Brown, N.A.C.; Jager, A.K.; Johnson, T.A. Smoke as a germination cue. Plant Spec. Biol. 2000, 15, 167-178. [CrossRef]

99. Abdollahi, M.R.; Mehrshad, B.; Moosavi, S.S. Effect of method of seed treatment with plant derived smoke solutions on germination and seedling growth of milk thistle (Silybum marianum L.). Seed Sci. Technol. 2011, 39, 225-229. [CrossRef] 
100. Modi, A.T. Indigenous storage method enhances seedling vigour of traditional maize. S. Afr. J. Bot. 2002, 98, 138-139.

101. Jamil, M.; Malook, I.; Parveen, S.; Naz, T.M.; Ali, A.; Jan, S.U.; Rehman, S.U. Smoke priming, a potent protective agent against salinity: Effect on proline accumulation, elemental uptake, pigmental attributes and protein banding patterns of rice (Oryza sativa). J. Stress Physiol. Biochem. 2013, 9, 169-183.

102. Aslam, M.M.; Jamil, M.; Khatoon, A.; El-Hendawy, S.E.; Al-Suhaibani, N.A.; Shakir, S.K.; Malook, I.; Rehman, S.U. Does weeds-derived smoke improve plant growth of wheat? J. Bio Mol. Sci. 2015, 3, 86-96.

103. Tieu, A.; Dixon, K.W.; Meney, K.A.; Sivasithamparam, K. Interaction of soil burial and smoke on germination patterns in seeds of selected Australian native plants. Seed Sci. Res. 2001, 11, 69-76. [CrossRef]

104. Thomas, T.H.; van Staden, J. Dormancy break of celery (Apium gravveolens L.) seeds by plant derived smoke extract. Plant Growth Regul. 1995, 17, 195-198. [CrossRef]

105. Kepczynski, J.; Cembrowska, D.; van Staden, J. Releasing primary dormancy in Avena fatua L. caryopses by smoke-derived butenolide. Plant Growth Regul. 2010, 62, 85-91. [CrossRef]

106. Soos, V.; Sebestyen, E.; Posta, M.; Kohout, L.; Light, M.E.; van Staden, J.; Balazs, E. Molecular aspects of the antagonistic interaction of smoke-derived butenolides on the germination process of Grand Rapids lettuce (Lactuca sativa) achenes. New Phytol. 2012, 196, 1060-1073. [CrossRef]

107. Nelson, D.C.; Riseborough, J.A.; Flematti, G.R.; Stevens, J.; Ghisalberti, E.L.; Dixon, K.W.; Smith, S.M. Karrikins discovered in smoke trigger Arabidopsis seed germination by a mechanism requiring gibberellic acid synthesis and light. Plant Physiol. 2009, 149, 863-873. [CrossRef]

108. Kulkarni, M.G.; Ascough, G.D.; van Staden, J. Effects of foliar applications of smoke-water and a smoke-isolated butenolide on seedling growth of okra and tomato. HortScience 2007, 42, 179-182. [CrossRef]

109. Kulkarni, M.G.; Sprag, S.G.; van Staden, J. Germination and post germination response of Acacia seeds to smoke-water and butenolide, a smoke derived compound. J. Arid. Environ. 2007, 69, 177-187. [CrossRef]

110. Taylor, J.L.S.; van Staden, J. Plant-derived smoke solutions stimulate the growth of Lycopersicon esculentum roots in vitro. Plant Growth Regul. 1998, 26, 77-83. [CrossRef]

111. Taylor, J.L.S.; van Staden, J. Root initiation in Vigna radiates (L.) Wilczek hypocotyls cuttings are stimulated by smoke-derived extracts. Plant Growth Regul. 1996, 18, 165-168. [CrossRef]

112. Ramos, D.M.; Valls, J.F.M.; Borghetti, F.; Ooi, M.K.J. Fire cues trigger germination and stimulate seedling growth of grass species from Brazilian savannas. Am. J. Bot. 2019, 106, 1190-1201. [CrossRef] [PubMed]

113. Ma, E.B.; Dixon, K.; Flematti, G. Comparative enhancement of germination and vigor in seed and somatic embryos by the smoke chemical 3-methyl-2H-furo[2,3-c] pyran-2-one in Tetraphyllum (Restionaceae). In Vitro Cell. Dev. Biol. Plant. 2006, 42, 306-308. [CrossRef]

114. Doherty, L.C.; Cohn, M.A. Seed dormancy in rice (Oryza sativa). Commercial liquid smoke elicits germination. Seed Sci. Res. 2000, 10, 415-421. [CrossRef]

115. Malook, J.; Shah, G.; Jan, M.; Shinwari, K.I.; Aslam, M.M.; Rehman, S.U.; Jamil, M. Smoke priming regulates growth and the expression of myeloblastosis and zinc-finger genes in rice under salt stress. Arab. J. Sci. Eng. 2017, 42, 2207-2215. [CrossRef]

116. Jain, N.; Soos, V.; Balazs, E.; van Staden, J. Changes in cellular macromolecules (DNA, RNA and protein) during seed germination in tomato, following the use of a butenolide, isolated from plant derived smoke. Plant Growth Regul. 2008, 54, 105-113. [CrossRef]

117. Zhou, J.; Da-Silva, J.A.T.; Ma, G. Effects of smoke water and karrikin on seed germination of 13 species growing in China. Cent. Eur. J. Biol. 2014, 9, 1108-1116. [CrossRef]

118. Gilbert, M.E.; Ripley, B.S. The effect of smoke on the photosynthetic gas exchange of Chrysanthemoides monilifera. S. Afr. J. Bot. 2002, 68, 525-531. [CrossRef]

119. Papenfus, H.B.; Kulkarni, M.G.; Jeffrey, M.P.; Finnie, F.; van Staden, J. Smoke-isolated trimethyl butenolide inhibits seed germination of different weed species by reducing amylase activity. Weed Sci. 2015, 63, 312-320. [CrossRef]

120. Jager, A.K.; van Staden, J. Soluble sugars in light-sensitive Grand Rapids lettuce seeds treated with red light, gibberellic acid and a plant-derived smoke extract. S. Afr. J. Bot. 2002, 68, 404-407. [CrossRef]

121. Baxter, B.J.M.; van Staden, J. Plant-derived smoke: An effective seed pre-treatment. Plant Growth Regul. 1994, 14, 279-282. [CrossRef] 
122. Akeel, A.; Khan, M.M.A.; Jaleel, H.; Din, U.M. Smoke-saturated water and karrikinolide modulate germination, growth, photosynthesis and nutritional values of carrot (Daucus carota L.). Plant Growth Regul. 2019, 38, 1387-1401. [CrossRef]

123. Meng, Y.; Chen, F.; Shuai, H.; Luo, X.; Ding, J.; Tang, S.; Liu, J. Karrikins delay soybean seed germination by mediating abscisic acid and gibberellin biogenesis under shaded conditions. Sci. Rep. 2016, 6, 1-12. [CrossRef]

124. Bieza, K.; Lois, R. An Arabidopsis mutant tolerant to lethal ultraviolet-B levels shows constitutively elevated accumulation of flavonoids and other phenolics. Plant Physiol. 2001, 126, 1105-1115. [CrossRef]

125. Peer, W.A.; Murphy, A.S. Flavonoids and auxin-transport: Modulators or regulators? Trends Plant Sci. 2007, 12, 556-563. [CrossRef] [PubMed]

126. De Klerk, G.J.; Guan, H.; Huisman, P.; Marinova, S. Effects of phenolic compounds on adventitious root formation and oxidative decarboxylation of applied indoleacetic acid in Malus 'Jork9'. Plant Growth Regul. 2011, 63, 175-185. [CrossRef]

127. Bennett, R.N.; Wallsgrove, R.M. Secondary metabolites in plant defense mechanisms. New Phytol. 1994, 127, 617-633. [CrossRef]

128. Pourmorad, F.; Hosseinimehr, S.J.; Shahabimajd, N. Antioxidant activity, phenol and flavonoid contents of some selected Iranian medicinal plants. Afr. J. Biotechnol. 2006, 5, 1142-1145.

129. Savio, L.E.B.; Astarita, L.V.; Santarem, E.R. Secondary metabolism in micropropagated Hypericum perforatum L. grown in non-aerated liquid medium. Plant Cell Tissue Organ Cult. 2011, 108, 465-472. [CrossRef]

130. Thanos, C.A.; Rundel, P.W. Fire-followers in chaparral: Nitrogenous compounds trigger seed germination. J. Ecol. 1995, 83, 207-216. [CrossRef]

131. Tieu, A.; Dixon, K.A.; Sivasithamparam, K.; Plummer, J.A. Germination of four species of native Western Australian plant using plant-derived smoke. Aust. J. Bot. 1999, 47, 207-219. [CrossRef]

132. Duermeyer, L.; Khodapanahi, E.; Yan, D.; Krapp, A.; Rothstein, S.J.; Nambara, E. Regulation of seed dormancy and germination by nitrate. Seed Sci. Res. 2018, 28, 150-157. [CrossRef]

133. Soos, V.; Juhasz, A.; Light, M.E.; van Staden, J.; Balazs, E. Smoke-water-induced changes of expression pattern in Grand Rapids lettuce achenes. Seed Sci. Res. 2009, 19, 37-49. [CrossRef]

134. Soos, V.; Sebestyen, E.; Juhasz, A.; Pinter, J.; Light, M.E.; van Staden, J.; Balazs, E. Stress-related genes define essential steps in the response of maize seedlings to smoke-water. Funct. Integr. Genom. 2009, 9, 231-242. [CrossRef]

135. Soos, V.; Sebestyen, E.; Juhasz, A.; Light, M.E.; Kohout, L.; Szalai, G.; Tandori, J.; van Staden, J.; Balazs, E Transcriptome analysis of germinating maize kernels exposed to smoke-water and the active compound KAR 1. BMC Plant Biol. 2010, 10, 236. [CrossRef]

136. Baldrianova, J.; Cerny, M.; Novák, J.; Jedelsky, P.; Brzobohaty, B. Arabidopsis proteome responses to the smoke-derived growth regulator karrikin. J. Proteom. 2015, 120, 7-20. [CrossRef] [PubMed]

137. Trinh, C.; Gevaert, L.; Kohout, L.; van Staden, J.; Verschaeve, L. Genotoxicity evaluation of two kinds of smoke-water and 3,7-dimethyl-2H-furo[2,3-c] pyran-2-one. J. Appl. Toxicol. 2010, 30, 596-602. [CrossRef]

138. Zhong, Z.; Kobayashi, T.; Zhu, W.; Imai, H.; Zhao, R.; Ohno, T.; Rehman, S.U.; Uemura, M.; Tian, J.; Komatsu, S. Plant-derived smoke enhances plant growth through ornithine-synthesis pathway and ubiquitin-proteasome pathway in soybean. J. Proteomics 2020, 221, 103781. [CrossRef]

139. Otori, M.; Murashita, Y.; Rehman, S.U.; Komatsu, S. Proteomic study to understand promotive effects of plant-derived smoke on soybean (Glycine max L.) root growth under flooding stress. Plant Mol. Biol. Rep 2020, 1-10. [CrossRef]

140. Zhou, J.; Xu, Z.X.; Sun, H.; Guo, L.P. Smoke-isolated karrikins stimulated tanshinones biosynthesis in Salvia miltiorrhiza through endogenous nitric oxide and jasmonic acid. Molecules 2019, 24, 1229. [CrossRef]

141. Guo, Y.; Zheng, Z.; Clair, J.J.L.; Chory, J.; Noel, J.P. Smoke-derived karrikin perception by the $\alpha / \beta$-hydrolase KAI2 from Arabidopsis. Proc. Natl. Acad. Sci. USA 2013, 110, 8284-8289. [CrossRef]

142. Waters, M.T.; Nelson, D.C.; Scaffidi, A.; Flematti, G.R.; Sun, Y.M.; Dixon, K.W.; Smith, S.M. Specialisation within the DWARF14 protein family confers distinct responses to karrikins and strigolactones in Arabidopsis. Development 2012, 139, 1285-1295. [CrossRef] [PubMed]

143. Kagiyama, M.; Hirano, Y.; Mori, T.; Kim, S.Y.; Kyozuka, J.; Seto, Y.; Yamaguchi, S.; Hakoshima, T. Structures of D14 and D14L in the strigolactone and karrikin signaling pathways. Genes Cells 2013, 18, 147-160. [CrossRef] [PubMed] 
144. Waters, M.T.; Scaffidi, A.; Sun, Y.K.; Flematti, G.R.; Smith, S.M. The karrikin response system of Arabidopsis Plant J. 2014, 79, 623-631. [CrossRef] [PubMed]

145. Janssen, B.J.; Snowden, K.C. Strigolactone and karrikin signal perception: Receptors, enzymes, or both? Front Plant Sci. 2012, 3, 296. [CrossRef] [PubMed]

146. Smith, S.M.; Li, J. Signaling and responses to strigolactones and karrikins. Curr. Opin. Plant Biol. 2014, 21, 23-29. [CrossRef]

147. Stanga, J.P.; Smith, S.M.; Briggs, W.R.; Nelson, D.C. SUPPRESSOR OF MORE AXILLARY GROWTH2 1 controls seed germination and seedling development in Arabidopsis. Plant Physiol. 2013, 163, 318-330. [CrossRef]

148. Stanga, J.P.; Morffy, N.; Nelson, D.C. Functional redundancy in the control of seedling growth by the karrikin signaling pathway. Planta 2016, 243, 1397-1406. [CrossRef]

149. Machin, D.C.; Hamon-Josse, M.; Bennett, T. Fellowship of the rings: A saga of strigolactones and other small signals. New Phytol. 2020, 225, 621-636. [CrossRef]

150. Yao, J.; Mashiguchi, K.; Scaffidi, A.; Akatsu, T.; Melville, K.T.; Morita, R.; Morimoto, R.; Smith, S.M.; Seto, Y.; Flematti, G.R.; et al. An allelic series at the KARRIKIN INSENSITIVE 2 locus of Arabidopsis thaliana decouples ligand hydrolysis and receptor degradation from downstream signaling. Plant J. 2018, 96, 75-89. [CrossRef]

151. Wang, L.; Waters, M.T.; Smith, S.M. Karrikin-KAI2 signalling provides Arabidopsis seeds with tolerance to abiotic stress and inhibits germination under conditions unfavorable to seedling establishment. New Phytol. 2018, 219, 605-618. [CrossRef] [PubMed]

152. Wang, L.; Xu, Q.; Yu, H.; Ma, H.; Li, X.; Yang, J.; Li, J. Strigolactone and karrikin signaling pathways elicit ubiquitination and proteolysis of SMXL2 to regulate hypocotyl elongation in Arabidopsis. Plant Cell 2020, 32, 2251-2270. [CrossRef] [PubMed]

Publisher's Note: MDPI stays neutral with regard to jurisdictional claims in published maps and institutional affiliations.

(C) 2020 by the authors. Licensee MDPI, Basel, Switzerland. This article is an open access article distributed under the terms and conditions of the Creative Commons Attribution (CC BY) license (http://creativecommons.org/licenses/by/4.0/). 